\title{
The Role of Stocking in the Reestablishment and Augmentation of \\ Native Fish in the Lower Colorado River Mainstream (1998-2002)
}

Open File Report 03-288
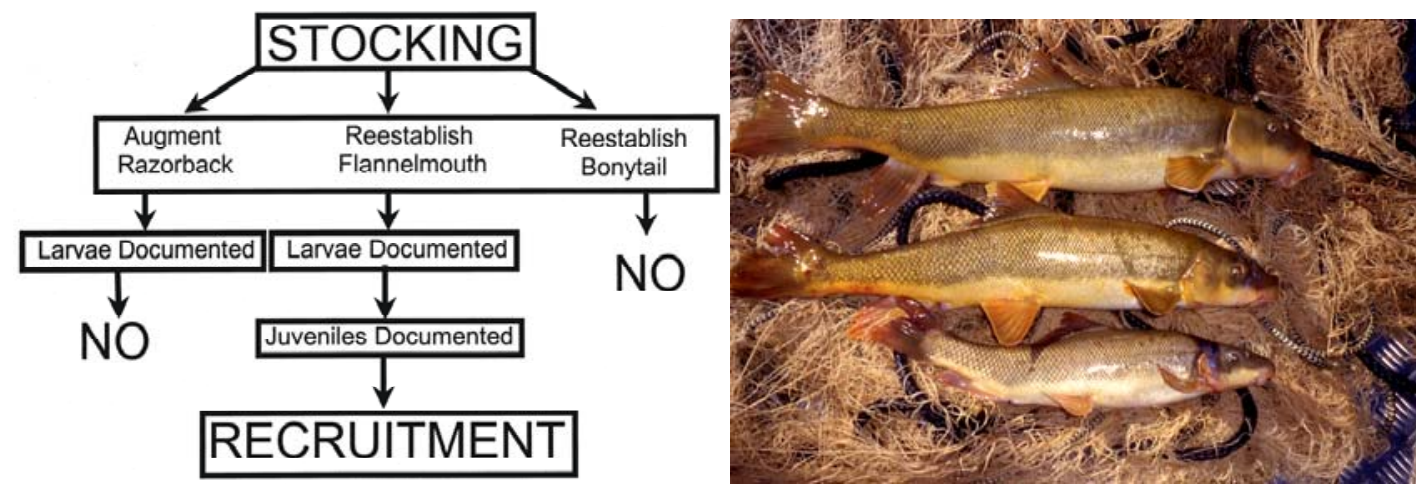

Multiple year classes of flannelmouth sucker

U.S. Department of the Interior

U.S. Geological Survey

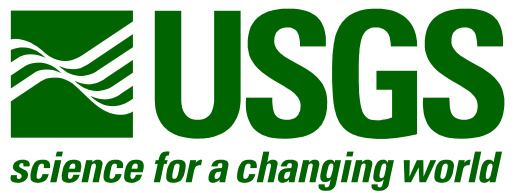

Prepared in Cooperation with Bureau of Reclamation Arizona State University U.S. Fish and Wildlife Service and California Fish and Game Department 


\section{The Role of Stocking in the Reestablishment and Augmentation of Native Fish in the Lower Colorado River Mainstream (1998-2002)}

By

Gordon Mueller, U.S. Geological Survey, Fort Collins Science Center ${ }^{1}$

Open-File Report 03-288

This report is preliminary and has not been reviewed for conformity with U.S. Geological Survey editorial standards (or with the North American Statigraphic Code). Any use of trade, product, or firm names is for descriptive purposes only and does not imply endorsement by the U.S. Government.

1. United States Geological Survey, P.O. Box 25007, D-8220, Denver, CO 80225 


\section{Table of Contents}

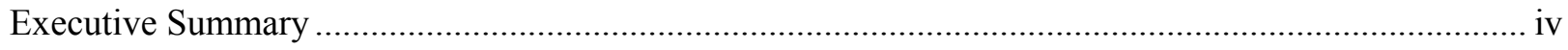

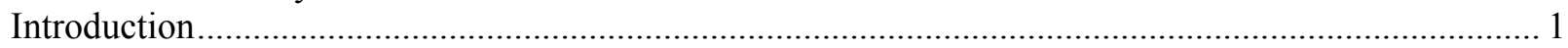

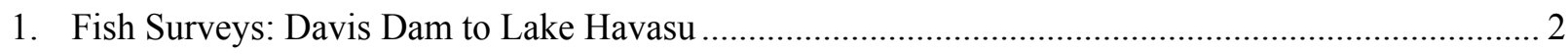

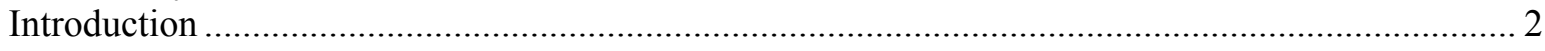

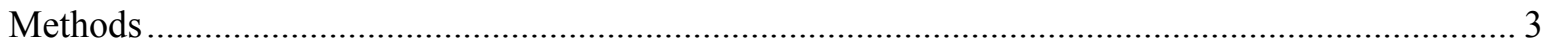

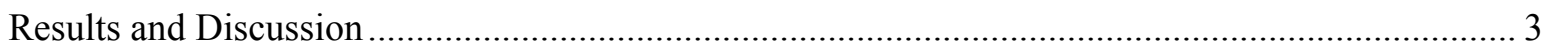

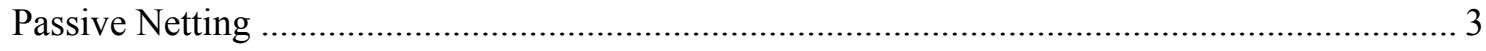

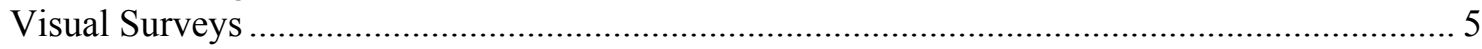

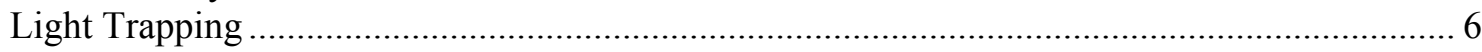

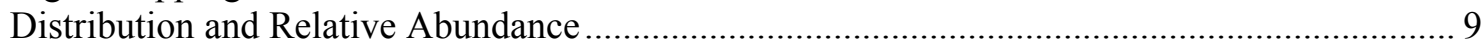

Physical Description of the Upper and Lower 40-km River Reaches .................................... 9

Differences in Fish Distribution and Relative Abundance ................................................... 9

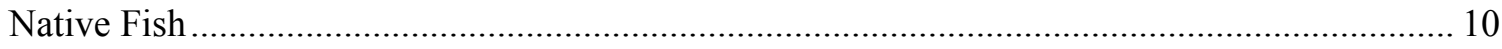

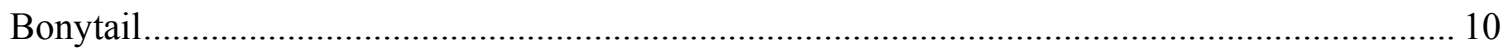

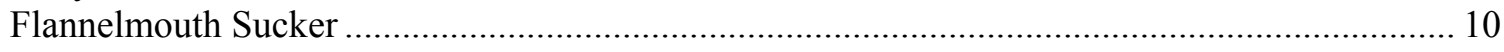

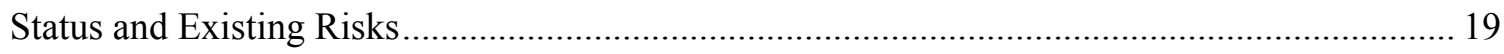

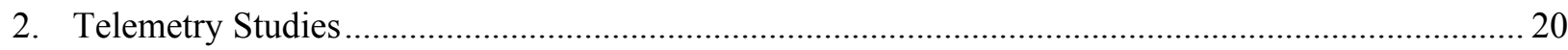

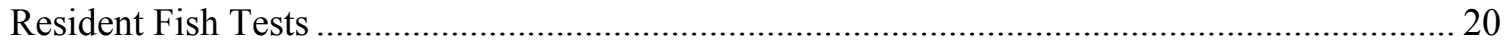

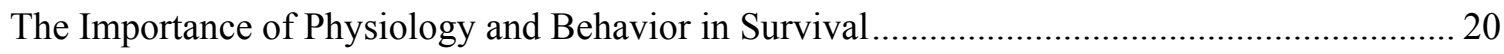

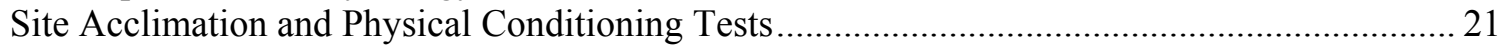

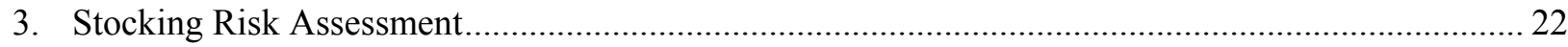

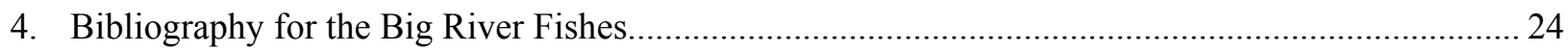

5. The Role of Stocking in Management and Recovery .............................................................. 25

Bonytail, Flannelmouth, and Razorback Suckers: Contrasting Survival Stories........................ 25

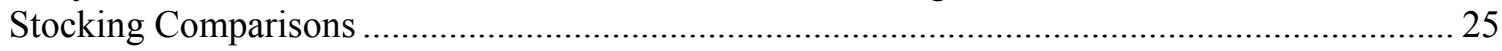

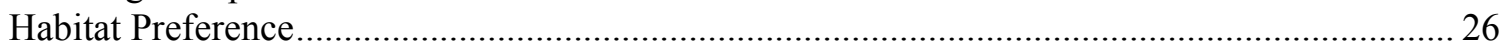

Results of the Recent Endangered Fish Stocking Programs ..................................................... 28

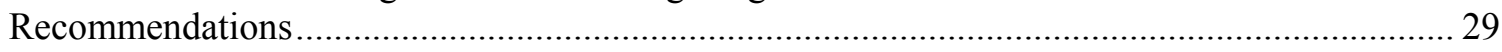

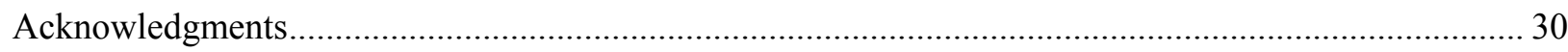

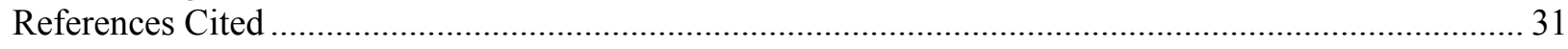

Appendix. Summary tables of fish numbers, average lengths, weights, and ranges............................... 35

Tables

1.1 Sample composition (\%) of fish collected in the Colorado River between Davis Dam and Lake Havasu from October 1999 to May 2002 


\section{Contents (continued)}

1.2 Standing crop estimates of common fish species based on 15-minute visual surveys $(\mathrm{n}=25)$ on the Colorado River channel between Davis Dam and Lake Havasu during August 2000 .............. 6

1.3 Summary of the location, effort, number, and species taken in the 2000 larval light trap effort..... 6

1.4 Summary of the location, effort, number, and species taken in the 2001 larval light trap effort..... 7

1.5 Summary of the location, effort, number, and species taken in the 2002 larval light trap effort..... 8

1.6 Summary of the movements of flannelmouth suckers determined by recaptures from 1999 to 2002

1.7 Population estimates for flannelmouth sucker based on multiple censuses using mark/recaptured

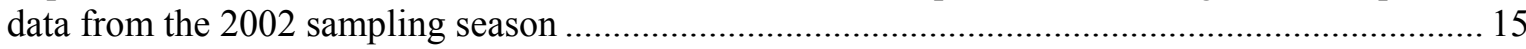

1.8 Estimation of flannelmouth sucker and razorback sucker population size based on visual surveys conducted in the Colorado River channel between Davis Dam and Lake Havasu during August 2000 16

1.9 Summary of the number, length, and weight ranges of razorback suckers captured between 1999 and 2002.

1.10 Summary of the sexual condition and timing of male and female razorback suckers captured in the Colorado River between Davis and Parker Dams 1999-2002

5.1 Summary of possible survival factors with the conflicting survival strategies used by flannelmouth and razorback suckers

Figures

1.1 General map of the study area showing dominant features located along the Colorado River

between Davis Dam and Lake Havasu....

1.2 Timing of larval fish emergence in the Colorado River between Davis Dam and Lake Havasu from February 19 to May 7, 2001

1.3 Comparison of catch per unit effort (fish $/ 100 \mathrm{~m}^{2}$ ) of fish taken from the Colorado River by 3.7-cm inner panel trammel nets set near Topock Gorge (RM 27-40) and the Laughlin area (RM 62-82)

1.4 Length distribution of flannelmouth suckers taken from spawning areas from 1999 to 2002 ........11

\section{Contents (concluded)}


1.5 Estimate of flannelmouth sucker age distribution based on annuli read from vertebrae and fin rays

1.6 Growth rates $(\mathrm{mm} / \mathrm{month})$ of flannelmouth sucker $(\mathrm{n}=57)$ recaptured after a minimum of 9 months after release from the lower Colorado River, Arizona-Nevada, between 1999 and 2002 (bars represent range)

1.7 Specific locations where flannelmouth suckers were observed spawning and their larvae found... 14

1.8 The occurrence and timing of sexually ripe flannelmouth suckers captured in the lower Colorado River, Arizona-Nevada .....

1.9 Locations where razorback suckers are suspected of spawning from the capture of sexually ripe adults and presence of larval suckers.

2.1 An output map from ArcView ranking the most suitable areas of the Colorado River between Davis and Parker Dams stock razorback suckers. The program covers the entire lower Colorado River....

23

5.1 Graph showing the relative abundance of razorback and flannelmouth suckers in the upper and lower 40-km reach of river found between Davis Dam and Lake Havasu, 1999-2002.

5.2 Summary graph showing the relative abundance of suspected nonnative predators in the upper and lower 40-km of river found between Davis Dam and Lake Havasu, 1999-2002 


\section{Executive Summary}

The Colorado River has experienced dramatic physical and biological change. Rated as the fifth largest river in the USA by volume, today its waters seldom reach the sea. Water diversions gradually reduce its flow to a point where its last remaining waters are diverted at Morales Dam leaving nearly $100 \mathrm{~km}$ of historic channel dry. In contrast, lower basin storage reservoirs cover $36 \%$ of the historic channel. Remaining portions of the flowing river have been channelized and straightened to a point where it now resembles a large canal. Levees, mechanical dredging, and the natural forces of erosion have degraded the river channel nearly $2 \mathrm{~m}$ in some locations, isolating it from its floodplain and affecting local water tables. The river no longer functions as a natural stream system characteristic of spring run-off, summer spates, and droughts. Today it serves as a water storage and conveyance system to meet human needs.

Physical change has been severe, but not as devastating as the biological pollution. More than 80 nonnative fish species have been introduced to the lower basin. Today, over 20 fish species have established, many forming economically important sport fisheries. As these alien species expanded their range, native communities rapidly declined and disappeared from much of their historic range. By 1930, most had become rare. The last remnant populations of bonytail, razorback sucker, and Colorado pikeminnow in the lower basin were taken downstream of Davis Dam during the 1960's and 1970's. Today, Colorado pikeminnow, and it appears, wild bonytail are extirpated downstream of Glen Canyon Dam, and wild razorback suckers are extremely rare. The Colorado River and its fish assemblage is a totally different ecosystem than it was a century ago.

State and federal agencies have been attempting to reestablish native communities for nearly three decades. More than 12 million razorback suckers, most of them small, were stocked between 1981 and 1991. Few of these fish survived and during the past decade managers have switched to stocking larger suckers to improve survival. Since 1995, nearly 18,000 bonytail and 30,000 large razorback suckers have been stocked in Lake Havasu. There was also a single stocking (611) of flannelmouth suckers in 1976. These programs have produced mixed results. The single introduction of flannelmouth sucker has resulted in a thriving community, estimated at more than 4,000 fish. This success spirited hopes by many that other natives would respond similarly but unfortunately, that has not occurred.

Initial stocking returns suggest that stocking survival of bonytail and razorback sucker is relatively poor $(<12 \%)$ and the absence of any detectable recruitment indicates present reintroduction efforts are falling short of anticipated survival or potential recovery. In contrast, the single introduction of wild flannelmouth sucker, out-performed millions of hatchery produced razorback sucker. This suggests hatchery reared fish may be inferior to wild fish in terms of survival skills, which has been found to be the case for terrestrial animal introductions. A review of culturing, stocking, and repatriation techniques is warranted which examines ways to better prepare fish to convert to natural foods, recognize predators, and be physically conditioned to cope with currents and hopefully avoid or escape predators.

Comparison of flannelmouth sucker success and the razorback sucker's failure provides compelling evidence that helps explain the dramatic physical habitat changes that have occurred and the possible role of habitat selection and predator communities. It mimics conditions observed in portions of the upper basin where flannelmouth suckers are still common but razorback suckers have been extirpated. Both sucker species are successfully spawning in the lower basin, however, recruitment can only be detected for flannelmouth. Habitat preference and associated predation pressure of those habitats appear to be the primary factors responsible for recruitment. Flannelmouth suckers prefer channel habitat that supports a fraction of the predators found in off-channel habitats where razorback suckers reside. The dependence of razorback sucker young on slack water habitat puts the species at a much higher predation risk. 
Through a process of trial and error during the past two decades, managers are now stocking large natives to increase their survival. Small native fish simply have not survived. While this improves short-term stocking survival, it ignores or at least delays dealing with the predation issue. Current stocking programs have reestablished or augmented relatively small populations of bonytail, razorback, and flannelmouth suckers between Davis and Parker Dams. All three species are better off than they were a decade ago in this section of the river. Unfortunately, bonytail and razorback sucker will only maintain a presence in the Colorado River main stem through continued stocking and it remains to be seen if management agencies will make that long-term commitment.

While the gains for the bonytail and razorback sucker have been difficult, the successful reintroduction of flannelmouth sucker highlights the ecological changes that have taken place and suggests this, and possibly other channel oriented species (i.e., Gila robusta) could be established. In contrast, there is no evidence to suggest we can expect similar recruitment or expansions for bonytail and razorback sucker. Their dependence on slack water habitat leaves their young vulnerable to overwhelming predation.

Recovery in the main stem will only be accomplished with a dramatic decrease and possibly a total removal of nonnative species. After ten years and over $\$ 6$ million in expenditures to remove nonnative fish it appears this philosophy is neither technically nor politically viable. In the meantime, stocking is the only alternative available to insure these species don't disappear. The only viable option appears the creation and maintenance of small, isolated refuge communities where these species have shown they can produce young. 


\section{Introduction}

The initial goal of this study was to determine the status, ecological requirements, and assess the role of stocking augmentation for the razorback sucker and bonytail in the lower Colorado River main stream. Unfortunately, funding rescissions (-60\%) made it necessary to reduce and refocus this study.

The study focused on the Mohave and Chemehuevis Valleys which contained the last remnant populations of wild bonytail and razorback sucker. Native fish populations in Lake Mohave have been the topic of extensive study for nearly four decades. Far less effort has been directed toward the lower Mohave Valley where natives were last reported inhabiting portions of the remaining, but altered river.

More than 30,000 razorback suckers and nearly 18,000 bonytail have been stocked in the Colorado River between Davis and Parker dams during the past decade. Fish were stocked by Arizona Game and Fish Department (AGFD), U.S. Fish and Wildlife Service (FWS), Bureau of Reclamation (BOR), and Bureau of Land Management (BLM); however, little effort has gone into examining their fate. For these reasons, we focused our remaining resources at examining the fish community found in the $60 \mathrm{~km}$ reach of river between Lake Havasu and Davis Dam.

The following report contains five chapters that represent the main components of the study. They include: 1. Fish Surveys: Davis Dam to Lake Havasu; 2. Telemetry Studies; 3. Stocking Assessment; 4. Bibliography for the Big River Fishes, Colorado River; and 5. The Role of Stocking in Management and Recovery. Additional information generated from this project is provided in the following papers and reports:

Marsh, G.A., and Mueller, G., 1999, Spring-summer movements of bonytail in a Colorado River reservoir, Lake Mohave, Arizona, and Nevada: USGS/BRD Open-File Report 99-103, Denver, Colo.

Marsh, P.C., and Kesner, and B.R., 2000, Movement of sub-adult razorback sucker in a regulated reach and reservoir of the Lower Colorado River: Cooperative agreement 1445-0009-94-1108, task 6, submitted to USGS, Denver, Colo.

Marsh, P.C., Pacey, C., and Mueller, G., 2001, Bibliography of the Big River Fishes, Colorado River, created at Arizona State University, Tempe, under contract to USGS, Denver, Colo.

Mueller, G.A., P.C. Marsh, G. Knowles, and T. Wolters. 2000. Distribution, movements, and habitat use of razorback sucker (Xyruchen texanus) in a lower Colorado River reservoir, Arizona-Nevada. Western North American Naturalist. vol. 60, p. 180-187.

Mueller, G.A., and Marsh, P.C., 2002, Lost, a desert river and its native fishes: A historical perspective of the Lower Colorado River, Information and Technology Report USGS/BRD/ITR-2002-0010, U.S. Government Printing Office, Denver, Colo, 69 p.

Mueller, G.A., Marsh, P.C., Foster, D., Ulibarri, M., and T. Burke. 2003. Factors influencing post-stocking dispersal of razorback sucker: North American Journal of Fisheries Management. vol. 23, p. 270-275.

Mueller, G.A., and Wydoski, R., In Press, Reintroduction of flannelmouth sucker (Catostomus latipinnis): North American Journal of Fisheries Management. 


\section{Fish Surveys: Davis Dam to Lake Havasu}

\section{Introduction}

The Colorado River bordered by Davis and Parker dams supports a diverse and impressive recreational fishery. Rainbow trout have been stocked in the cool tailwaters of Davis Dam for over 50 years. Lake Havasu supports an economically important black bass fishery. During the past decade, more than 875 acres of habitat structures were placed throughout the reservoir as part of the Lake Havasu Fisheries Improvement Program. A recent economic report estimated the project is generating more than $\$ 18$ million annually by nonresident anglers to the local economy (Anderson, 2001).

Historically, this section of river contained the last remnants of the main stem native fishes in the lower basin. Topock Marsh and other associated backwaters located between Fort Mohave and Needles, California provided nearly 1,740 ha of off-channel nursery habitat (Beland 1953). While Davis Dam was being constructed (1950-1954), Jonez and Sumner (1954) observed both bonytail and razorback sucker young in the vicinity of the new dam and a large number of young were collected at Cottonwood Landing in 1950 (Miller 1961). This represented the last documentation of significant numbers of young for either species in a river environment. The last Colorado pikeminnow taken from the lower main stream was captured from Lake Mohave by an angler in 1962; anglers continued to take bonytail from the river near Bullhead City until the mid-1970's (Minckley, 1979; Mueller and Marsh, 2002). A few razorback suckers lingered in the area until the late 1990's, possibly dating back to the pre-dredging era (1950's).

Closure of Davis Dam and the filling of Lake Mohave caused a brief resurgence of bonytail and razorback sucker production. The new reservoir trapped native fish and initial flooding apparently mimicked conditions necessary to sustain young. Bonytail and razorback sucker communities rapidly expanded in the early years until nonnative predators over whelmed their progeny (McCarthy and Minckley, 1987). The resulting native community numbered in the tens of thousands (Minckley, 1983). This community has been the topic of study for nearly four decades by faculty from Arizona State University and the University of Nevada-Las Vegas. Assisted by other state and federal agencies, wild populations have been monitored and hatchery-reared fish have been stocked to augment declining wild stocks. More than 55,000 razorback sucker and similar numbers of bonytail (as of 2003) have been stocked in Lake Mohave to augment those populations. The objective of the razorback sucker stocking program is to maintain the community through artificial production by using innovative methods designed to maintain the genetic diversity of the population (Mueller, 1995).

Natives found in the river between Parker and Davis Dams have received less scrutiny. In 1976, 611 flannelmouth suckers were stocked and during the past decade, 30,000-razorback sucker and 18,000 bonytail were also introduced. During the past 3 years, FWS and other agencies have conducted an annual, one-week survey of Lake Havasu. However, there has not been an intensive effort to assess these specific introductions. In recent years, state biologists reported collecting multiple year classes of flannelmouth sucker during annual fish surveys. It was hoped the factors that allowed the survival of flannelmouth juveniles may also benefit razorback sucker. The objectives of this study included:

1. describe the fish community found in the $80 \mathrm{~km}$ portion of the river downstream of Davis Dam, with special interest in bonytail, flannelmouth sucker, and razorback sucker,

2. determine what factors contributed to the successful colonization of the flannelmouth sucker,

3. identify spawning locations used by the natives, and

4. determine the survival rate of stocked fish. 


\section{Methods}

The $60 \mathrm{~km}$ of river extending from the tailrace of Davis Dam (RM-82, Fish-n-Map Comp.) to Catfish Bay (RM-25) was sampled during a four-year period (1999-2002) (Figure 1.1). Surveys were conducted between the months of December and May when both sucker species spawn. Working during the winter and early spring also avoided conflicts with recreationalists that visit the area during the summer.

Trammel nets were used to minimize fish stress and mortalities. Net lengths and mesh sizes varied in order to capture all life stages of fish. Nets were $2 \mathrm{~m}$ deep and lengths ranged from 25 to $50 \mathrm{~m}$. Three mesh sizes were used, 1.2, 2.5, and 3.8-cm. Nets were generally set off jetties and in backwaters where currents were mild and nets were less apt to collect debris. Sampling occurred at night with nets set just prior to dusk and pulled at dawn.

Initial surveys conducted in 1999 and 2000 sampled approximately every $3 \mathrm{~km}$ along the $60 \mathrm{~km}$ reach. During these cold months, we found that the vast majority of fish were concentrated into off-channel habitats such as Davis Dam tailrace, Laughlin Lagoon, Boy Scout Camp, Park Moabi, Golden Shores, Pulpit Rock, Tampas Wash, Blankenship Bend and others. Sampling in 2001 and 2002 focused on locations where fish were found concentrated.

Biweekly sampling surveys were based out of Big Bend State Park in Laughlin, Nevada, and Park Moabi, California. When adequate help was available, two survey crews worked both sites. When only one crew was available, they worked Park Moabi during January through early March and the Laughlin area from February through April. Fish data included: gear type, location, species, total length, weight, and sexual condition. Native fish were implanted with a passive integrated transponder (PIT) that allowed us to identify individual fish. Recapturing these marked fish provided information pertaining to growth, movement, and population size. Collections did result in some net mortality. Fin rays, vertebrae, and otoliths were collected for the netting mortalities to age flannelmouth suckers. Global Positioning System (GPS) coordinates were taken for all razorback suckers, bonytail, and for flannelmouth suckers collected in California waters as requested by the state.

Sampling in the main channel proved impractical due to water depth $(3 \mathrm{~m})$ and currents. A method of visually surveying fish from a boat was developed and standardized. We used time intervals of 15 minutes (fish \#/15 minutes), similar to electrofishing and used a GPS to measure the distance we traveled. Only fish observed within $10 \mathrm{~m}$ of either side of the boat were counted to standardize our survey width. A member of the crew would stand on the bow and count fish while another kept record. We idled downstream at about 6 $\mathrm{km} /$ hour. Standing crop was calculated based on fish $/ \mathrm{m}^{2}$ and $\mathrm{kg} / \mathrm{m}^{2}$. Populations were estimated based on the river's surface area of the river reach.

Light traps were used in 2000, 2001, and 2002 to help identify when and where spawning was taking place. Quatrefoil, Plexiglas traps were equipped with internal lights that attracted fish into the trap. Traps were generally set along shore at dusk and collected at dawn. Samples were generally examined in the field. Larval fish were removed and preserved for laboratory analysis. Larval sucker identification was verified by the Larval Fishes Laboratory, Fort Collins, Colorado, and through voucher specimens.

\section{Results and Discussion}

\section{Passive Netting}

More than 8,000 fish were collected during the 4-year effort (Table 1.1). Nineteen species (3 native, 16 introduced) were represented. Due to the successful introduction of flannelmouth sucker, native species (flannelmouth and razorback sucker) made up $40 \%$ of the catch in the Laughlin area. A total of 238 razorback sucker, 1,355 flannelmouth suckers, and 1 bonytail were captured. 


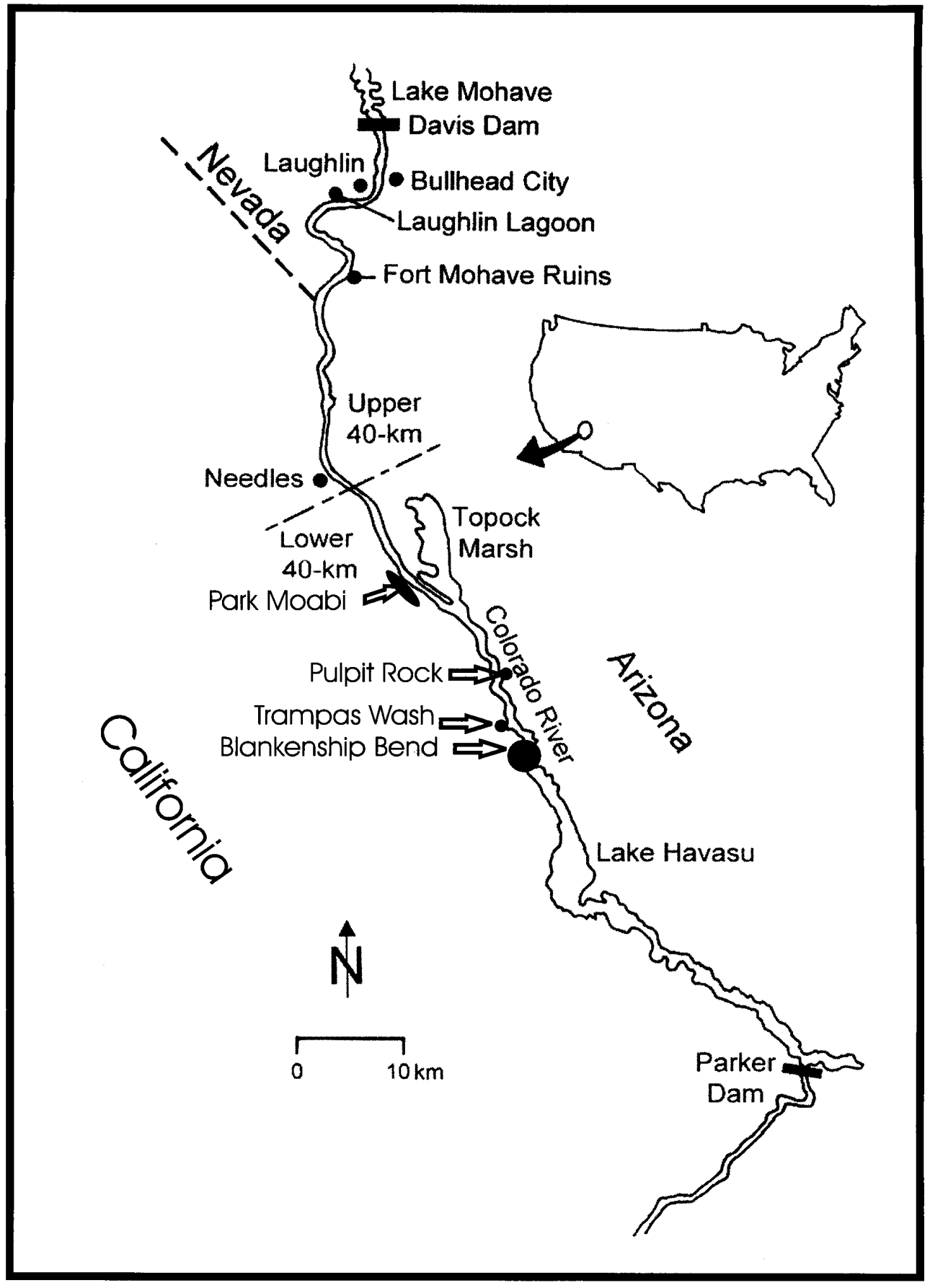

Figure 1.1. General map of the study area showing dominant features located along the Colorado River between Davis Dam and Lake Havasu. 
Table 1.1. Sample composition (\%) of fish collected in the Colorado River between Davis Dam and Lake Havasu from October 1999 to May 2002.

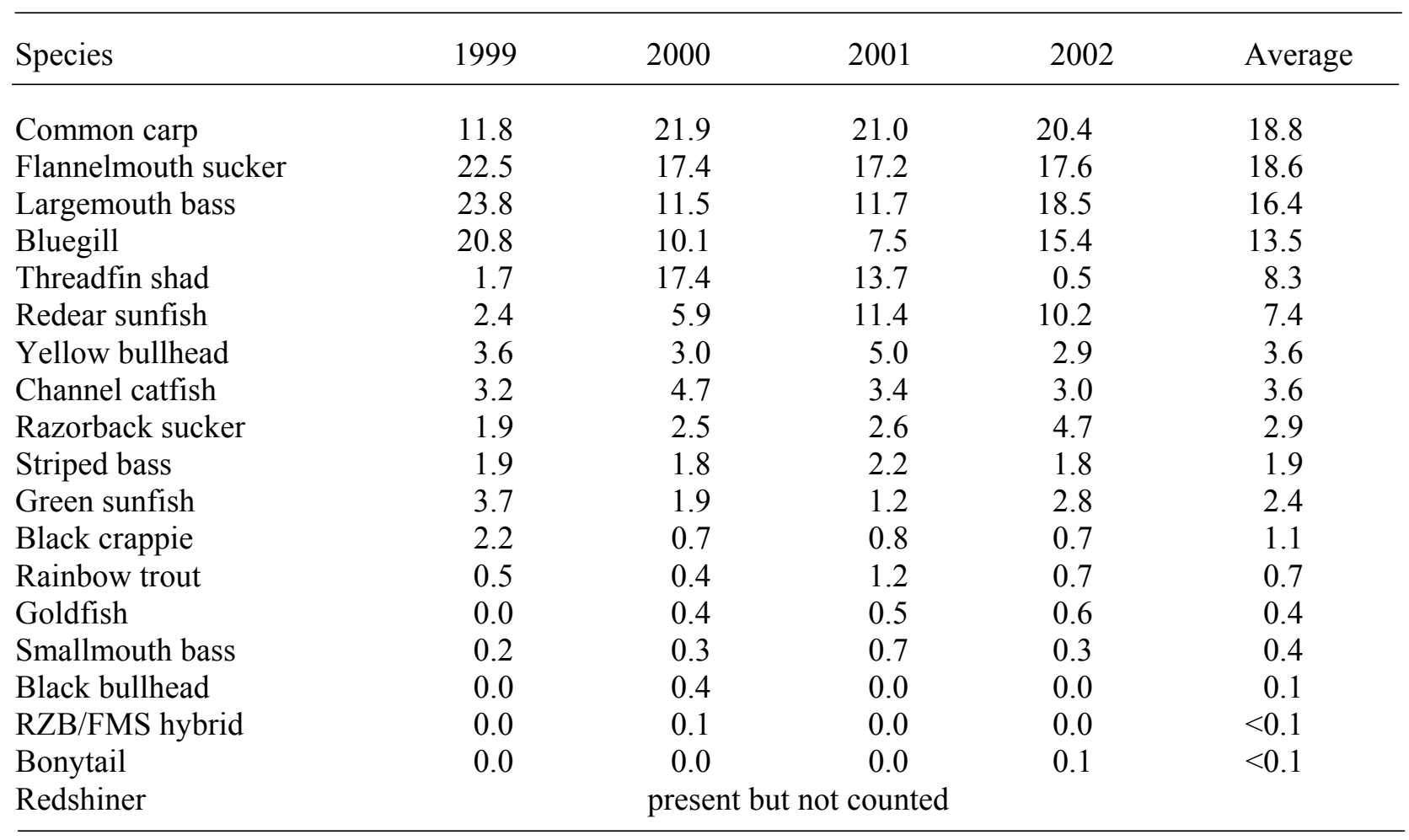

Common carp (18.8\%) was the most prevalent species captured, followed by largemouth bass (16.4\%), flannelmouth sucker (18.6\%), bluegill (13.5\%), threadfin shad (8.3\%), redear sunfish $(7.4 \%)$, and others $(17.0 \%)$ (Table 1.1). Species composition was relatively stable over the 4-year period.

Normally, fish lengths were recorded, however weights were not always taken. We often experienced problems with digital scales and felt it unnecessary to measure the more numerous species (threadfin shad and common carp). A summary of fish numbers, average lengths, weights, and ranges is shown in the appendix.

We sampled river wide in 2000 but captured and saw few fish in the main stem channel. Netting suggested that fish were concentrated in the slack or backwater areas. There were distinctive seasonal shifts in fish distribution. Fish appeared to concentrate in backwaters during the winter. While we continued to sample some channel areas, the majority of netting in 2001 and 2002 centered in backwater areas where fish were more abundant and more easily captured.

\section{Visual Surveys}

Twenty-five (15 minute) surveys were completed between Davis Dam and Lake Havasu. We observed 2,172 fish during the 6.25-hour effort (Table 1.2). Eight species or groups of fish could be easily identified. Common carp was the most numerous $(56.3 \%)$, followed by striped bass $(23.8 \%)$; flannelmouth sucker (13.4\%); channel catfish (3.5\%); black bass (smallmouth and largemouth bass) $(2.1 \%)$; razorback sucker $(0.1 \%)$; and sunfish $(0.1 \%)$. Flannelmouth sucker and young striped bass were generally found in large $(>50)$ schools. 
Table 1.2. Standing crop estimates of common fish species based on 15-minute visual surveys $(n=25)$ on the Colorado River channel between Davis Dam and Lake Havasu during August 2000.

\begin{tabular}{lrrrrr}
\hline Species & Number & Percent & Weight $(\mathrm{g})$ & Fish/ha & $\mathrm{Kg} / \mathrm{ha}$ \\
\hline & & & & & \\
Common carp & 1,222 & 56.3 & 1,824 & 36.2 & 66.0 \\
Striped bass & 516 & 23.8 & 677 & 15.3 & 10.4 \\
Channel catfish & 77 & 3.5 & 1,002 & 2.3 & 2.3 \\
Black bass & 47 & 2.1 & 716 & 1.4 & 1.0 \\
Flannelmouth sucker & 290 & 13.4 & 1,000 & 8.6 & 8.6 \\
Razorback sucker & 3 & 0.1 & 190 & 0.06 & 0.08 \\
Others & 17 & 0.8 & 1,000 & 0.5 & 0.5 \\
Totals & 2,172 & 100.0 & & 64.4 & 88.8 \\
\hline
\end{tabular}

Fish densities averaged 64.4 fish/ha and $88.8 \mathrm{~kg} / \mathrm{ha}$ based on average weights of fish collected by trammel net. Relative abundance decreased with distance downstream as habitat diversity decreased. This approach appeared best suited for large fish and estimates were undoubtedly conservative since small, cover-oriented fish or those at depths $>4 \mathrm{~m}$ were difficult or impossible to see. These surveys also excluded more productive backwaters where sampling suggested the majority of fish were found.

\section{Light Trapping}

2000 Effort

In 2000, 24 overnight samples were collected between 21 February and 10 May for a total of 384 trap hours of effort (Table 1.3). Sampling during the months of February and March precluded spawning of other fish species. Four flannelmouth sucker larvae were collected, all from the Laughlin Lagoon area and two razorback sucker larvae were collected from Park Moabi.

Table 1.3. Summary of the location, effort, number, and species taken in the 2000 larval light trap effort.

\begin{tabular}{lcccccc}
\hline Location & \# of sets & Effort (h) & RZB & FMS & Cyprinids & Centrarchids \\
\hline Laughlin Lagoon & 8 & 128 & 0 & 4 & 3,304 & 38 \\
Boy Scout Camp & 6 & 96 & 0 & 0 & 250 & 4 \\
Park Moabi & 6 & 96 & 2 & 0 & 0 & 0 \\
Topock Bay & 1 & 16 & 0 & 0 & 0 & 0 \\
Pulpit Rock & 3 & 48 & 0 & 0 & 0 & 0 \\
& 24 & 384 & 2 & 6 & 3,554 & 42 \\
\hline
\end{tabular}


The sampling effort in 2001 increased and started 19 January, which was earlier and began prior to the spawning season. This resulted in 36 sets that did not collect any fish larvae. We captured a similar number $(3,602)$ of larvae from the 30 samples that did collect fish (Table 1.4). Most (>95\%) were cyprinids (common carp) and centrarchids $(<5 \%)$. Traps were placed at the tailrace of Davis Dam, Laughlin Lagoon, Boy Scout Camp, Park Moabi, Topock Bay, Pulpit Rock (Topock Gorge), and Blankenship Bend.

Six razorback suckers were captured, four at Park Moabi and two at Blankenship Bend. Eight flannelmouth suckers were captured, all in the Bullhead City region. Traps also attracted dense swarms of zooplankton, Odonate and Mayfly nymphs, diving beetles, and freshwater prawns or glass shrimp (Palaemonetes spp.). Water temperatures averaged $14^{\circ} \mathrm{C}\left(10-17^{\circ} \mathrm{C}\right)$ during the period.

2002 Effort

Fifty-three light trap samples were collected between 16 January and 25 April (Table 1.5). Four larval razorback suckers were captured near Park Moabi and Pulpit Rock. No larval flannelmouth suckers were captured.

The presence of sucker larvae showed that both species had successfully spawned but larvae were geographically separated, suggesting species were spawning in different areas. All sexually active flannelmouth suckers and their larvae were collected in the upper $16 \mathrm{~km}$ region of the study area. It is believed spawning extended downstream another $8 \mathrm{~km}$; however, this area was not sampled due to an absence of backwaters. It is interesting to note that flannelmouth larvae were not captured in the lower 40-km river reach. Likewise, razorback sucker larvae were also site specific. A total of 12 were collected during the 3 years. All were found in the lower 40-km reach, between the Park Moabi and Blankenship Bend areas. This coincided with where sexually active adults were collected.

\section{Larval Emergence}

The timing that fish larvae emerged provides compelling evidence that razorback suckers may be more vulnerable to predators. Razorback sucker larvae appeared prior to other fishes, making them vulnerable to predators emerging from their winter fast. Flannelmouth suckers on the other hand, spawn later, well into the spawn of other species (Figure 1.2). Emerging with thousands of other larvae may increase their chance for survival as more food becomes available to predators.

Table 1.4. Summary of the location, effort, number, and species taken in the 2001 larval light trap effort.

\begin{tabular}{lccccrr}
\hline Location & \# of sets & Effort $(\mathrm{h})$ & RZB & FMS & Cyprinids & Centrarchids \\
\hline Davis Dam & 2 & 32 & 0 & 0 & 6 & 0 \\
Laughlin Lagoon & 14 & 224 & 0 & 3 & 2,951 & 120 \\
Big Bend Park & 3 & 48 & 0 & 0 & 240 & 0 \\
Boy Scout Camp & 5 & 80 & 0 & 5 & 403 & 25 \\
Park Moabi & 4 & 64 & 4 & 0 & 19 & 9 \\
Blankenship Bend & 2 & 32 & 2 & 0 & 0 & 4 \\
Total & $30^{\text {a }}$ & 480 & 6 & 8 & 3,619 & 158 \\
\hline
\end{tabular}

${ }^{\mathrm{a}}$ Total number of samples was 66 but only 30 contained fish. Total effort was 1,056 hr.

Table 1.5. Summary of the location, effort, number, and species taken in the 2002 larval light trap effort. 
Location $\quad$ \# of sets $\quad$ Effort (h) $\quad$ RZB $\quad$ FMS $\quad$ Cyprinids

Centrarchids

$\begin{array}{lrrrrrr}\text { Laughlin Lagoon } & 19 & 304 & 0 & 0 & 502 & 27 \\ \text { Big Bend Park } & 6 & 96 & 0 & 0 & 1 & 3 \\ \text { Boy Scout Camp } & 9 & 144 & 0 & 0 & 52 & 5 \\ \text { Golden Shores } & 1 & 16 & 0 & 0 & 0 & 0 \\ \text { Park Moabi } & 10 & 160 & 3 & 0 & 0 & 0 \\ \text { Pulpit Rock } & 1 & 16 & 1 & 0 & 0 & 0 \\ \text { Blankenship Bend } & 6 & 96 & 0 & 0 & 0 & 0 \\ \text { Total } & 53 & 848 & 4 & 0 & 555 & 35\end{array}$

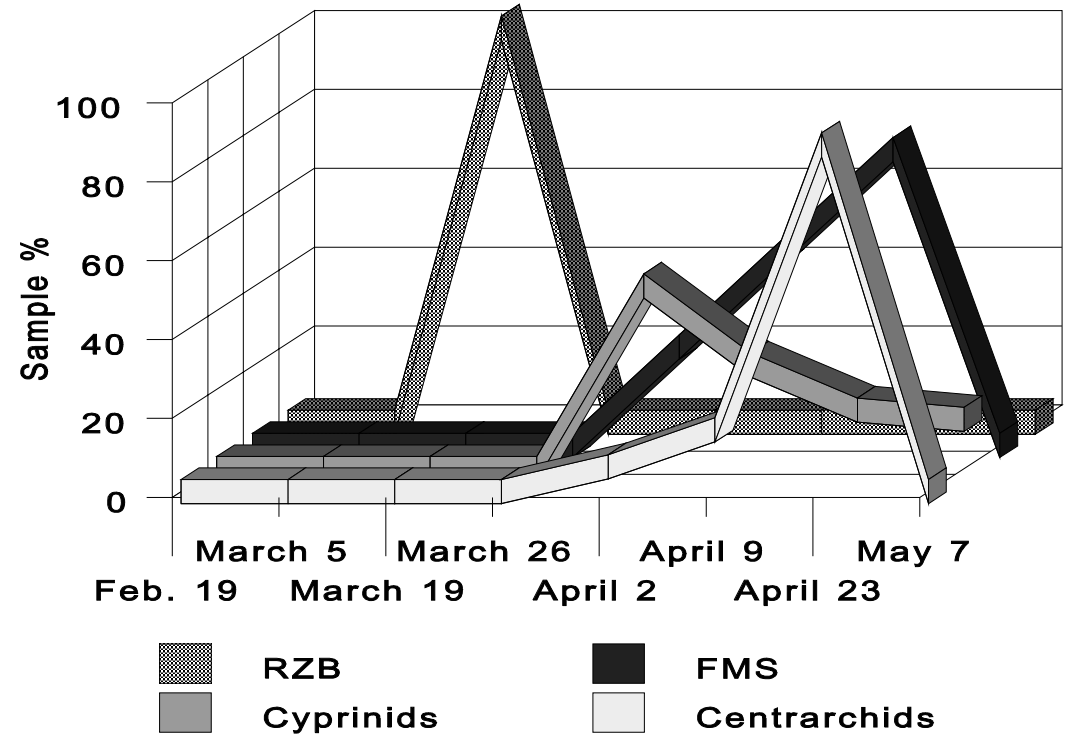

Figure 1.2. Timing of larval fish emergence in the Colorado River between Davis Dam and Lake Havasu from February 19 to May 7, 2001.

Distribution and Relative Abundance 
Species composition and relative abundance varied significantly in relation to location and habitat availability. Habitat characteristics changed dramatically as one moved downstream and typically fell into three primary categories: (1) the tailwater downstream of Davis Dam, (2) the dredged river channel, and (3) the backwater complexes located near Lake Havasu. The study area was divided into two 40-km reaches for purposes of comparing potential differences in the up- and downstream fish communities. The upper reach was dominated by channel and tailwater habitat while the fish community in the lower river reach was influenced by the reservoir and large backwaters.

\section{Physical Description of the Upper and Lower 40-km River Reaches}

The first characteristic of the upper reach was Davis Dam's tailwater, which included a $20-\mathrm{km}$ reach of physically degraded channel downstream of Davis Dam. This reach was represented by a relatively broad, and in some areas, braided river channel composed primarily of large gravels and rock. Channel depth varied from swift runs to scoured pools, some exceeding $20 \mathrm{~m}$ in depth. There were two relatively large ( $>10 \mathrm{ha})$ backwaters, one at Laughlin Lagoon and the other at Boy Scout Camp. Both were relatively shallow $(<1 \mathrm{~m})$ and experienced daily river stage fluctuations $(1.5 \mathrm{~m})$, which exposed large expanses of mud flats. Fluctuations caused by hydropower were less evident in downstream areas.

The 40-km reach between the old Fort Mohave ruins to Topock Gorge was dredged in the 1950's and 1960's. Here the river was bordered by levees and the channel was seldom wider than $150 \mathrm{~m}$. The riverbed seldom exceeded depths greater than $3 \mathrm{~m}$ and was composed primarily of drifting sand. This reach extended through the broad floodplain where the river channel historically extended nearly $3 \mathrm{~km}$ wide during spring runoff in the Topock Marsh area. Dredging and levee construction had either drained or isolated these wetlands. Backwaters or floodplain wetlands were absent from the river until one reached Park Moabi, located some $15 \mathrm{~km}$ downstream of Needles, California.

Large shallow backwaters that were typically bordered by large expanses of cattail dominated the third and last zone. The first backwater or lagoon was found at Park Moabi and represents the old Colorado River channel prior to dredging. The second occurred at Golden Shore, which again was a remnant of the historic channel. The river then entered the confines of Topock Gorge, which eventually opened up to large numbers of backwaters and a vast marshy delta before the river entered Lake Havasu.

\section{Differences in Fish Distribution and Relative Abundance}

Habitat availability influences fish composition and relative abundance. This was evident not only for recreational species but also in the distribution and relative abundance of native suckers. Channel habitat dominates the upper $40-\mathrm{km}$ reach where flannelmouth suckers are concentrated near Davis Dam. The flannelmouth sucker was the predominant species captured in that reach $\left(3.5 \mathrm{fish} / 100 \mathrm{~m}^{2}\right)$ and exceeded all other species (Figure 1.3). Nearly all (93\%) flannelmouth suckers were captured in the upper reach.

By contrast, nearly all razorback suckers were captured in the lower 40-km reach. Here, backwaters were prevalent and predators (i.e., bullhead, sunfish, black bass, and striped bass) were typically more than twice as abundant compared to the upstream reach (Figure 1.3). This suggests each sucker species faced a different predator community in terms of composition and abundance. Predators were twice as abundant in the lower 40-km reach and were dominated by redear sunfish, largemouth bass, bluegill, striped bass, smallmouth bass, and bullhead spp. Predators were far less abundant in the upper reach that was inhabited by flannelmouth sucker and only channel catfish were slightly more abundant (Figure 1.3). 


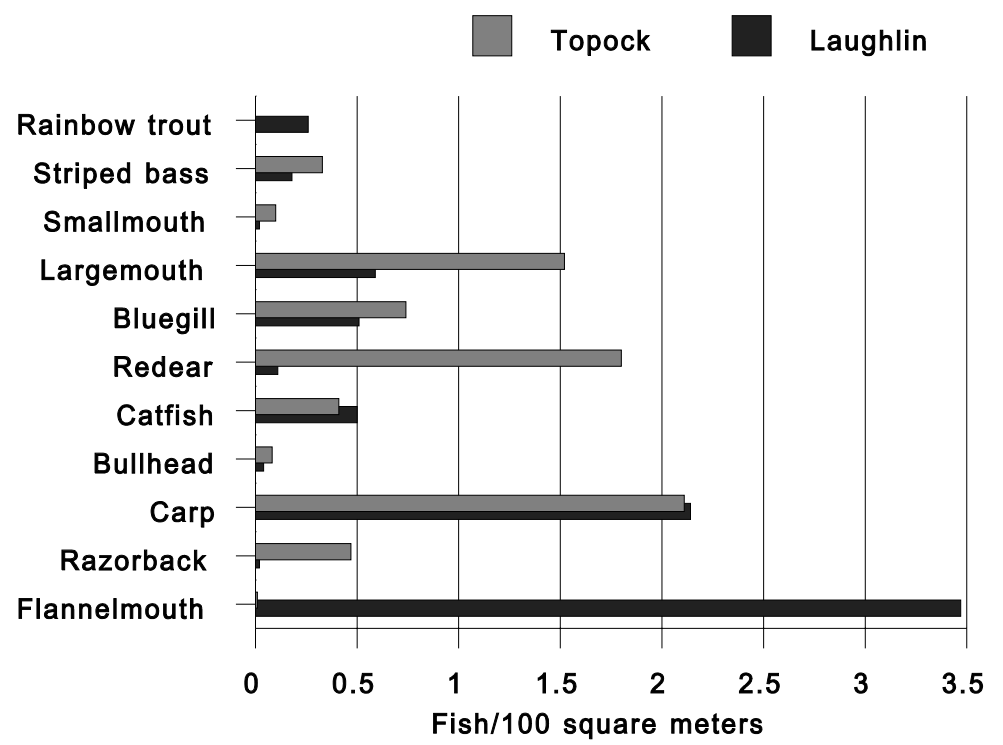

Figure 1.3. Comparison of catch per unit effort (fish/100 $\mathrm{m}^{2}$ ) of fish taken from the Colorado River by 3.7cm inner panel trammel nets set near Topock Gorge (RM 27-40) and the Laughlin area (RM 62-82).

\section{Native Fish}

Three native species were captured during this study; the bonytail, flannelmouth sucker, and razorback sucker. All three species have been stocked. The following section describes our findings.

\section{Bonytail}

Only one bonytail was captured during the study. It was taken near Bullhead City and represented the first capture in this region in nearly three decades. Approximately 18,000 bonytail have been stocked in Lake Havasu. The species must be considered extremely rare, representing only $0.0125 \%$ of the fish captured during this study. Telemetry studies in Lake Mohave, suggest that bonytail prefer deeper canyon habitats (Marsh and Mueller, 1999). It is quite possible these fish are remaining further downstream in Lake Havasu were we did not sample but there is also evidence that survival may be poor.

We were contacted by a fishing guide from Lake Havasu City that informed us that one of his clients had caught a $5.4 \mathrm{~kg}$ striped bass near Blakenship Bend. When the fish was dressed, they found its stomach contained $6,25 \mathrm{~cm}$ long bonytail.

\section{Flannelmouth Sucker}

A total of 766 flannelmouth suckers were PIT-tagged, the vast majority being taken upstream of Bullhead City Park (RM-71). Flannelmouth suckers appeared to be concentrated from Davis Dam downstream $30 \mathrm{~km}$. Most (90\%) flannelmouth suckers were captured during their spawning season (January through May), where fish were routinely taken at the Boy Scout Camp jetty and in the mouth of Laughlin Lagoon.

Most suckers (73\%) taken near Laughlin Lagoon were females. A large school of suckers were typically observed just upstream of the lagoon's entrance. Their numbers would swell to $>200$ fish during the spawning season. Presumed males were positioned along the bottom and were loosely dispersed $(1 \mathrm{~m})$ at depths $>2 \mathrm{~m}$. The substrate within this school had many discolored or lighter areas where it appeared the bottom had been recently disturbed. We observed actual spawning acts that caused clouds of detritus to be 
flushed from the substrate.

Since flannelmouth suckers were stocked in the Bullhead City area in 1976, the population has expanded. We encountered one angler that was specifically fishing for them. By all accounts, flannelmouth suckers were historically rare in the lower Colorado River and were not reported by Dill (1944) or Moyle (1976). Minckley (1973) reported only five collections taken downstream of Lake Mead. There are no reports of flannelmouth sucker being found in the vicinity of Lake Havasu and Mohave Valley prior to 1976.

Size distribution. Annual size distribution trends were similar for 1999, 2000, and 2001. While immature fish were taken $(<5 \%)$, the majority were spawning adults that averaged $529(\mathrm{n}=60), 528(\mathrm{n}=466)$, and 542 $\mathrm{mm}(\mathrm{n}=463)$, respectively. Size distribution in $2002(\mathrm{~N}=349)$ was bimodal and unique, in that it represented an old cohort and a strong year class of young adults. Average size of the larger ( $>425 \mathrm{~mm})$ cohort increased $(568 \mathrm{~mm}) 27 \mathrm{~mm}$ from 2001 while a smaller cohort $(30-40 \mathrm{~cm})$ constituted $31 \%$ of the sample (Figure 1.4).

Aging. The majority of growth occurs by age 6 and the majority $(76 \%)$ examined $(n=119)$ were 8 to 13 years old (Figure 1.5). The oldest sucker encountered was 24 years, which was substantially younger than a 39-year-old fish reported by Minckley (Scoppettone and Vinyard, 1991). All three aging structures suffered from weak or fuzzy annuli that hindered accurate aging, especially after age 10. Aging was difficult due to the study area's mild climate and cool waters released from Lake Mohave. These factors prevented development of sharp annuli on aging structures.

Growth data. Recaptures of 57 PIT-tagged flannelmouth suckers provided us growth data. As expected, smaller fish growth rates were much greater than larger fish. Fish between 450 and $475 \mathrm{~mm}$ grew at a rate of $4.51 \mathrm{~mm} / \mathrm{month}$ (Figure 1.6). This declined to $2.25 \mathrm{~mm} / \mathrm{month}$ for $50-\mathrm{cm}$ fish and $1.34 \mathrm{~mm} / \mathrm{month}$ for fish up to $525 \mathrm{~cm}$. Growth rates leveled off for fish between 525 and 600 at 1.02 and $1.04 \mathrm{~mm} / \mathrm{month}$. Growth further declined to 0.52 and $0.35 \mathrm{~mm} / \mathrm{month}$ for the largest fish. Based on these growth averages, we estimated a $60-\mathrm{cm}$ flannelmouth would be close to $14+$ years old.

Fish movements. More than 160 flannelmouth suckers were recaptured at least one month after being PIT-tagged and released (Table 1.6). The majority were mature females $(68 \%)$ had returned to their point of capture at least 12 months later. This was normally at or near suspected spawning areas. Ten (8\%) females returned two consecutive years.

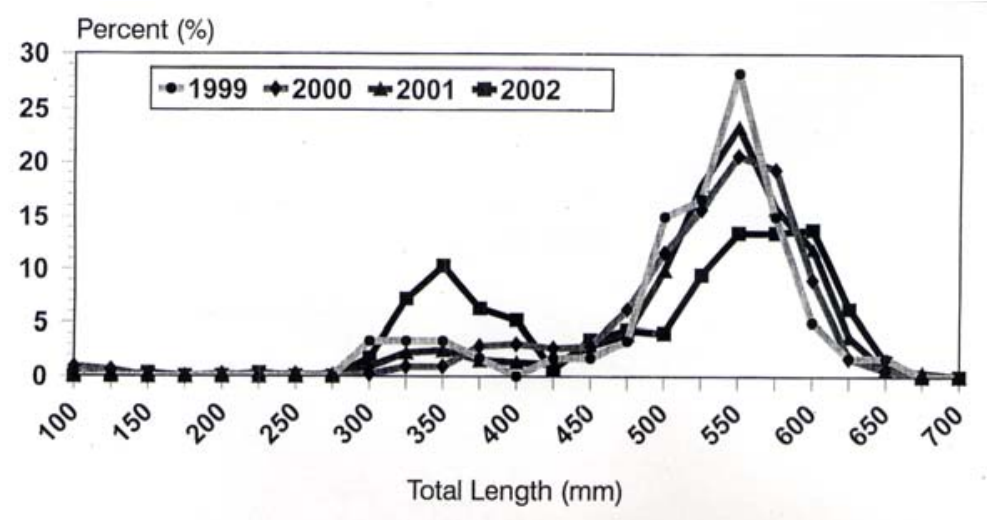

Figure 1.4. Length distribution of flannelmouth suckers taken from spawning areas from 1999 to 2002. 


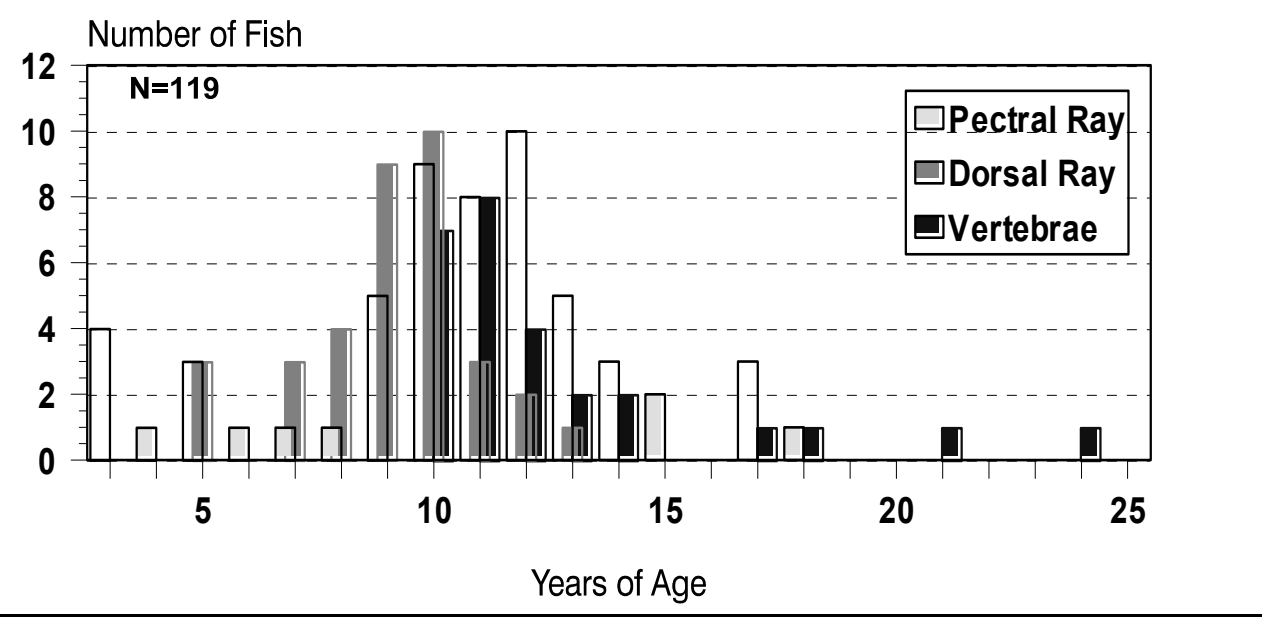

Figure 1.5. Estimate of flannelmouth sucker age distribution based on annuli read from vertebrae and fin rays.

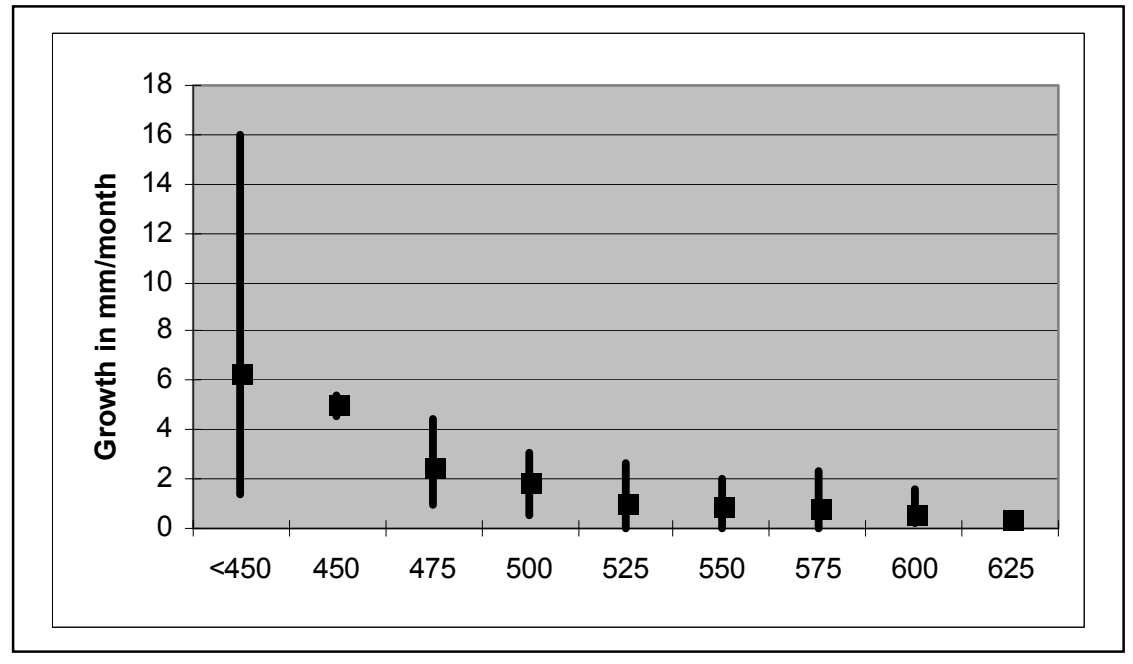

Figure 1.6. Growth rates $(\mathrm{mm} / \mathrm{month})$ of flannelmouth sucker $(\mathrm{N}=57)$ recaptured after a minimum of 9 months after release from the lower Colorado River, Arizona-Nevada between 1999 and 2002 (bars represent range). 
Table 1.6. Summary of the movements of flannelmouth suckers determined by recaptures from 1999 to 2002.

\begin{tabular}{lccrrrrr}
\hline Sex & Recaptured & $>12$ months & $\mathrm{R}^{1}$ & $\mathrm{R}^{2}$ & $\mathrm{R}^{3}$ & $\mathrm{~km}$ & $\max \mathrm{km}$ \\
\hline Females & 121 & 82 & 58 & 10 & 2 & 3.5 & 56.4 \\
Males & 24 & 12 & 11 & 0 & 0 & 1.4 & 3.2 \\
Immature & 15 & 12 & 11 & 0 & 0 & 0.6 & 12.1 \\
\hline
\end{tabular}

$\mathrm{R}^{1}=$ returned to the same location the following year.

$\mathrm{R}^{2}=$ returned to the same location two years.

$\mathrm{R}^{3}=$ returned to the same location three years.

Females range more than immature fish or males. The average distance detected for recaptured females was $3.5 \mathrm{~km}$, compared to 1.4 and $0.6 \mathrm{~km}$ for immature fish and males. The maximum movement observed was a female who traveled $56 \mathrm{~km}$ in one week. That movement was downstream and could have been triggered by netting and handling stress.

Spawning. Two large schools of suckers were commonly observed, one near the entrance of Laughlin Lagoon and another near the ruins of Fort Mohave (Figure 1.7). Smaller schools $(<25)$ were seen from Harrah's Casino, downstream to just below the Bullhead City Water Craft Launching Facility. Typically, these schools' number ranged from 10 to 100, but during the spawning season they could swell to more than 200 fish. During spawning (March-April), fish (presumed males) were observed dispersed and resting on the bottom. Occasionally a larger fish (presumed females) would enter the area where she would attract males. Actual spawning was observed several times and was similar to previous reports (Weiss and others, 1998).

Suckers also appeared to move into Laughlin Lagoon during the evening. We did not witness, but suspect that suckers were also spawning in the lagoon's entrance. The lagoon was deepened by dredge in 1999, which provided fish a clean substrate. Hydroelectric power cycles causes a constant current through the lagoon's entrance as it fluctuated through a daily cycle of filling and draining. Culverts located upstream also contributed to flow inside the backwater. The vast majority of the flannelmouth suckers were captured near the lagoon's entrance.

The depth at which we observed spawning was much deeper than previous reports (Chart and Bergersen, 1992; Thieme, 1997; Weiss and others, 1998). Depth varied due to hydropower cycles but spawning depth normally ranged between 2 and $3 \mathrm{~m}$. Substrate was composed of large gravels and cobble aggregate that was covered with algae and periphyton. Spawning fish would disturb the substrate, causing circular patterns of cleaned material that were noticeable from the surface. Velocities were not measured but appeared to be in the 0.5 to $1 \mathrm{~m} / \mathrm{sec}$ range.

Flannelmouth suckers were sexually active during the entire months of March and April. Females were found expressing gametes during this 8 week period, while ripe males were found as early as October through June. The prolonged spawning season allowed us to captured more than 250 sexually active fish, the majority freely expressing gametes. We collected 46 ripe females and 163 ripe males and 56 males that were not ripe but were tuburculate. Ripe females averaged $57 \mathrm{~cm}$ and ranged in size between 46 and $62 \mathrm{~cm}$. Ripe males were slightly smaller, averaging $52 \mathrm{~cm}(33-61 \mathrm{~cm})$ and similar in size to tuberculate males $(36-58 \mathrm{~cm})$. The majority of ripe females (43\%) were taken during the first half of April while we captured the most males $(28 \%, \mathrm{n}=46)$ during the last half of April (Figure 1.8). 


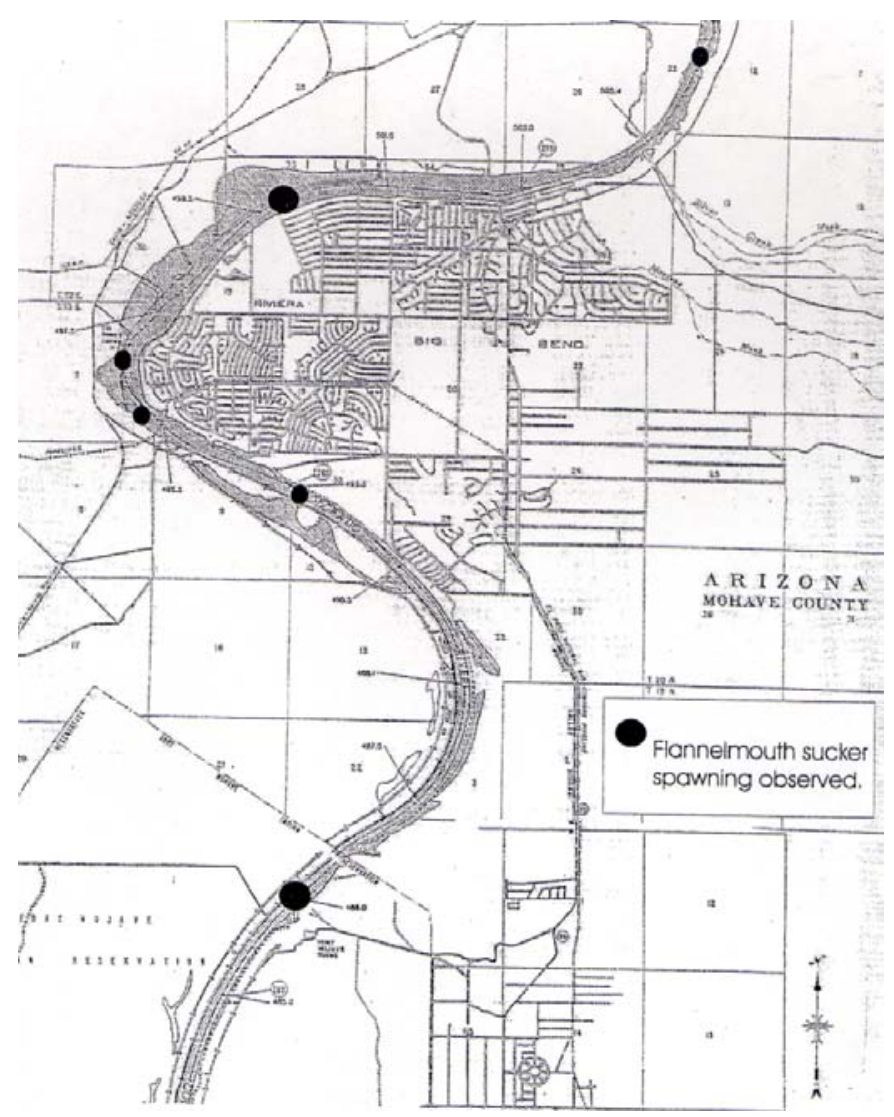

Figure 1.7. Specific locations where flannelmouth suckers were observed spawning and their larvae found.

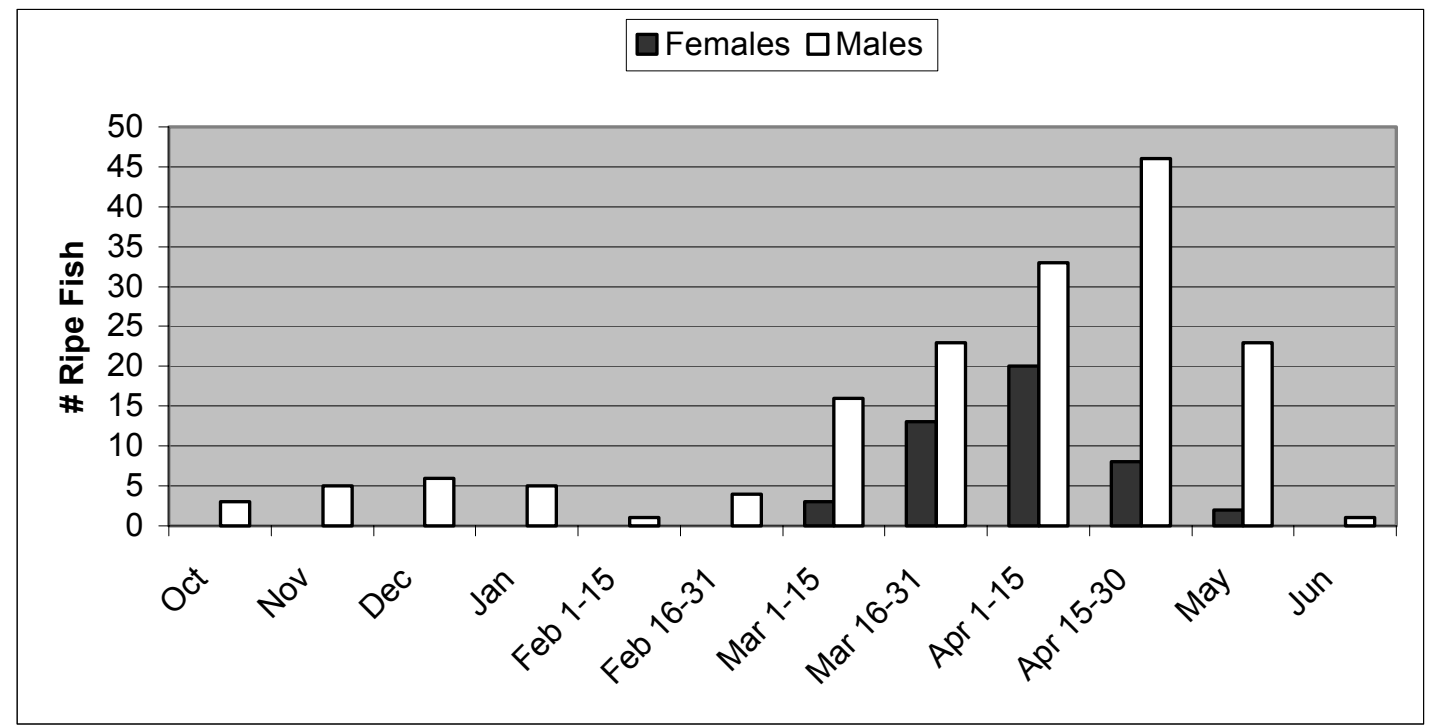

Figure 1.8. The occurrence and timing of sexually ripe flannelmouth suckers captured in the lower Colorado River, Arizona-Nevada.

Population estimates. Population size was estimated using two methods: (1) mark/recapture data, and (2) 
visual surveys conducted by boat. Six hundred ninety-four flannelmouth suckers were marked (PIT) by January 2002. Fish were collected during eight field trips in 2002 (Table 1.7). Based on the SchumarcherEschmeyer mark-recapture method, it is estimated the flannelmouth sucker population numbered 2,286 (95\% $\mathrm{CL}=1,847-2,998)$.

Due to known sampling biases, population estimates are presented with caution. Our flannelmouth sucker sample is heavily biased toward females and habitats where females convalesce between spawning events. Channel habitats where flannelmouth suckers are typically found are impractical to sample because of depth $(>2 \mathrm{~m})$ and current $(>50 \mathrm{~cm} / \mathrm{sec})$.

Schools of flannelmouth suckers were commonly observed in the main channel between Harrah's Casino and the old Fort Mohave ruins. Fish were typically observed near or on the bottom at 2 to $4 \mathrm{~m}$ depths over small cobble. The two largest groups, which often numbered over 100 fish, were found year-round just upstream from the entrance to Laughlin Lagoon and along the Arizona shoreline near the Fort Mohave ruins. Unfortunately, depth made electrofishing ineffective and swift currents and suspended debris made trammel nets impractical. We set hoop nets without any success and snags made drift nets impractical.

Fish are most susceptible to capture during their spawning season, which runs from February through May. Sexual dichotomy is prevalent in dispersal and behavior patterns. Males were primarily found in channels near spawning areas while females concentrated at the entrance of Laughlin Lagoon and smaller slack waters. Females are multiple spawners and we suspect they convalesced or rested in these slack water areas between spawning events.

Table 1.7. Population estimates for the flannelmouth sucker based on multiple censuses using mark/recaptured data from the 2002 sampling season.

\begin{tabular}{|c|c|c|c|c|}
\hline Date & Captured & Marked & Recaptured & $\mathrm{N}=\mathrm{MC} / \mathrm{R}^{\mathrm{a}}$ \\
\hline January $15-16$ & 23 & 715 & 2 & \\
\hline February $12-14$ & 18 & 736 & 6 & 2,208 \\
\hline February 26-28 & 3 & 747 & 2 & 1,121 \\
\hline March 12-14 & 56 & 747 & 22 & 1,901 \\
\hline March 26-28 & 47 & 779 & 12 & 3,051 \\
\hline April 9-11 & 76 & 812 & 36 & 1,714 \\
\hline April 23-25 & 64 & 844 & 18 & 3,001 \\
\hline May 7-8 & 42 & 888 & 17 & 2,194 \\
\hline \multirow[t]{3}{*}{ CL 95\% } & & & $\mathrm{n}=$ & 2,286 \\
\hline & & & $1,847^{\mathrm{b}}$ & \\
\hline & & & $2.998^{\mathrm{b}}$ & \\
\hline
\end{tabular}

*Adjusted for replicate recaptures and mortalities.

${ }^{a}$ Based on Schumacher-Eschmeyer method (Ricker, 1975).

${ }^{\mathrm{b}}$ Pearsons $95 \% \mathrm{CL}$. 
Both flannelmouth and razorback suckers were observed during visual surveys. Flannelmouth suckers were generally restricted to a 32-km reach downstream of Davis Dam while razorback suckers were distributed throughout the entire study area. Based on observed densities (fish/ha) and surface area of the Colorado River channel, large adult flannelmouth sucker numbers exceeded 4,000 fish while razorback sucker numbers in the main stem were estimated at $<100$ (Table 1.8). We suspect this is a fairly accurate depiction for channel densities, especially since razorbacks prefer backwater habitats that were not included in these calculations. (Initial sampling in 2003 indicated that juvenile flannelmouth suckers were fairly common in the Topock region. This would suggest the extent of the flannelmouth sucker population may be larger than that used in the estimate.)

\section{Razorback Suckers}

Far less was learned about razorback suckers due to the relatively low numbers captured. A multi-agency razorback sucker 'round-up' was held in 2001 and 2002 to mark and recapture razorback suckers found between Davis and Parker Dams. Approximately 30 razorback suckers were captured in the reservoir; the majority were in the upper portions of Lake Havasu and the river immediately upstream to Davis Dam. Several fish stocked at Winsor Beach (Lake Havasu) were recaptured more than $100 \mathrm{~km}$ upstream.

The vast majority of the 238 fish captured were taken from Park Moabi Lagoon (111), while fewer numbers were taken at Pulpit Rock (19), Blankenship Bend (19), Laughlin Lagoon (71), below Davis Dam (6), and scattered locations. The majority (67) of razorback suckers taken from Laughlin Lagoon were fish recently stocked in 2000 . There were also approximately 30 razorback suckers collected by AGFD, which were recent stocks. The recently stocked fish were excluded from Table 1.9. We encountered only three fish over $600 \mathrm{~mm}$ that could have been considered 'wild fish'.

Spawning. Unlike the relic population in Lake Mohave or the flannelmouths below Davis Dam, we were unable to actually observe spawning aggregates. Attempts to locate spawning groups using telemetry equipment failed due to equipment failure or poor signal strength. Helicopter over-flights during 2002 and 2003 located what appeared to be a large school of fish off the Blankenship Bend sand bar and other locations, but subsequent sampling only encountered common carp. We suspect fish are spawning in the more productive and turbid backwaters where observations may not be possible (Figure 1.9.). For instance, in Park Moabi where we suspect spawning occurred, water visibility was $<1 \mathrm{~m}$.

Trammel netting did produce relatively high numbers of ripe males in Park Moabi Lagoon and the Blankenship Bend area (Table 1.10). Net sets during the spawning season typically yielded one or two fish per set. One set along a rocky shoreline in Park Moabi yielded five ripe males. We captured razorback sucker larvae at this location in 2000, 2001, and 2002 and at Pulpit Rock and Blankenship Bend. We suspect razorback suckers were spawning at or near these locations.

Table 1.8. Estimation of flannelmouth sucker and razorback sucker population size based on visual surveys conducted in the Colorado River channel between Davis Dam and Lake Havasu during August 2000.

\begin{tabular}{lccr}
\hline Species & Density (ha) & Area (ha) & Population size \\
\hline Flannelmouth sucker & 8.6 & $480^{\mathrm{a}}$ & 4,128 \\
Razorback sucker & 0.06 & $1.350^{\mathrm{b}}$ & 81 \\
\hline
\end{tabular}

${ }^{a}$ Based on the estimated surface area of the $32 \mathrm{~km}$ of the Colorado River channel (150 m width) reach downstream of Davis Dam.

${ }^{b}$ Based on estimated surface area of the Colorado River channel between Davis Dam and Lake Havasu. 
Table 1.9. Summary of the number, length, and weight ranges of razorback suckers captured between 1999 and 2002.

\begin{tabular}{lccccc}
\hline Year & Number & Length $(\mathrm{mm})$ & Range & Weight $(\mathrm{g})$ & Range \\
\hline 1999 & 11 & 435 & $273-608$ & 1,056 & $206-2,306$ \\
2000 & 68 & 495 & $304-606$ & 1,373 & $314-2,374$ \\
2001 & 84 & 432 & $296-605$ & 1,006 & $272-2,427$ \\
2002 & 28 & 470 & $381-596$ & 1,254 & $628-2,356$ \\
Total & $171^{\text {a }}$ & 458 & $273-608$ & 1,172 & $206-2,427$ \\
\hline
\end{tabular}

${ }^{\mathrm{a}}$ Excluded 67 recently stocked fish in Laughlin Lagoon.

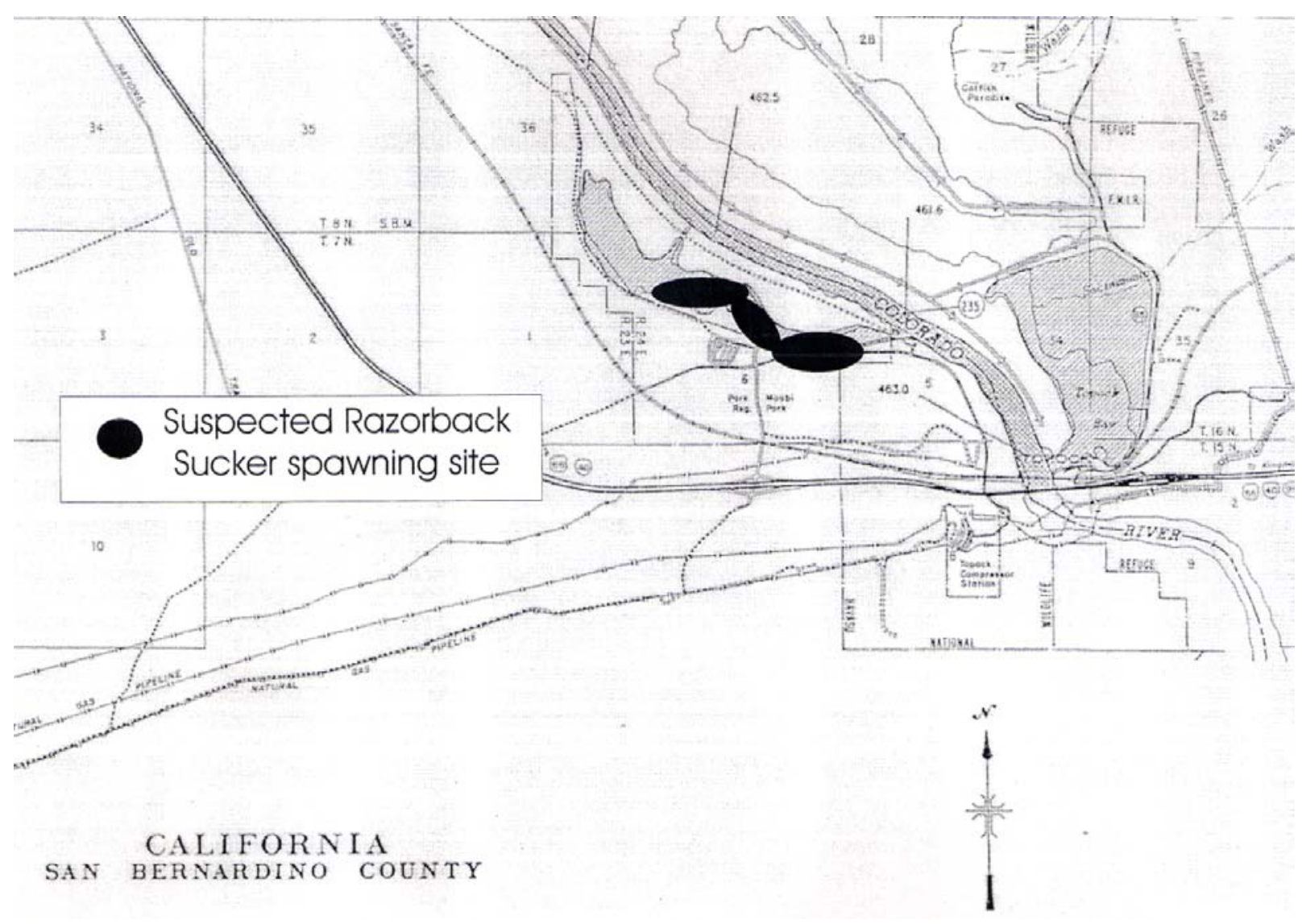

Figure 1.9. Locations where razorback suckers are suspected of spawning from the capture of sexually ripe adults and presence of larval suckers. 
Table 1.10. Summary of the sexual condition and timing of male and female razorback suckers captured in the Colorado River between Davis and Parker Dams, 1999-2002.

\begin{tabular}{lrrrrrrr}
\hline $\begin{array}{c}\text { Sex and condition } \\
(\%)\end{array}$ & $\#$ & TL $(\mathrm{mm})$ & December & January & February & March & April \\
\hline Ripe males & 28 & $327-512$ & 4 & 14 & 11 & 71 & 0 \\
Tuberculate males & 26 & $326-520$ & 4 & 12 & 15 & 65 & 4 \\
Ripe females & 1 & 560 & 0 & 0 & 100 & 0 & 0 \\
Total/average & 55 & $326-560$ & $4 / 0$ & $13 / 0$ & $13 / 100$ & $68 / 0$ & $2 / 0$ \\
\hline
\end{tabular}

We collected nearly twice as many males as females (82-42). The overwhelming majority (97\%) of fish expressing gametes were males $(\mathrm{n}=28)$. In addition, we collected another 26 tuburculate males (Table 1.10). Ripe males were captured from December through March. Only one ripe female was taken.

The inability to find concentrations of spawners may have been caused by the immaturity of females and the virtual absence of wild fish. For instance, do the younger fish know where to spawn? Males become sexually active within 1-3 years while it takes females 5-6 years (Minckley, 1973). Nearly all the males captured during February and March of 2001 and 2002 were ripe, while only two females produced eggs. In one case, the eggs were freely expressed while in the other they were forced and were abnormally small. The majority of stocking occurred after 1996, suggesting most of the fish were younger than 6 years old and had not reached full sexual maturity. Chances of finding spawning groups should increase with time.

Growth rates. Three razorback suckers were recaptured nearly a year after being PIT-tagged. All appeared to be young fish and had growth rates greater than the $2 \mathrm{~mm} /$ year reported for the relic Lake Mohave (Pacey and Marsh, 1998). The smallest male (435 mm) grew at a rate of $31.3 \mathrm{~mm} /$ year. The larger male (482 $\mathrm{mm})$ and female $(504 \mathrm{~mm})$ grew 16.8 to $14.4 \mathrm{~mm} /$ year, respectively. These rates bracketed the 9.1 to 20.1 $\mathrm{mm} /$ year growth rates reported for razorback suckers in Lake Mead (Holden and others, 2001). It is interesting to note that razorback sucker growth was substantially less than similar sized flannelmouth suckers.

Movement data. Movement data is more qualitative than quantitative. Not all fish were checked for magnetic wire tags, but the majority of those scanned proved to be fish that were released at Windsor Beach in Lake Havasu. Several of these fish were captured more than $90 \mathrm{~km}$ upstream near Davis Dam. Coordinated sampling during 2001 and 2002 suggest that stocked fish prefer the river and inflow habitat.

We also captured eight razorbacks that had been stocked in Lake Mohave. While some fish may have moved downstream during a spill in 1999, the only explanation for suckers stocked after than time is that they traveled through Davis Dam's Power Plant. The passage of these fish through the turbines is troubling, when one considers the numbers that were (are) possibly killed by turbine strike. It also suggests similar losses are, or can, occur not only at Parker Dam, but also at the Central Arizona Project and Metropolitan Water District diversions. The perceived absence of razorback suckers from the lower canyon reaches of Lakes Mohave and Havasu may reflect the fish's preference for upstream habitats, but it may also indicate suckers are being lost in these areas.

Population estimate. Approximately 30,000 large $(>25 \mathrm{~cm})$ razorback suckers have been stocked in Lake Havasu since 1995. Thus far, there has not been any attempt to estimate their survival. We PIT-tagged a total of 156 suckers during the course of our sampling. The number of recaptured razorback suckers was low and often fish were recaptured shortly after being initially marked.

Estimates based on our marked population. We recaptured 3 suckers in 2001 that we had marked in previous years. At that time, we had PIT-tagged 73 suckers and captured 68 that year. Based on a simple Peterson's mark/recapture ratio, the population was estimated at 1,655 razorback suckers. Likewise, we recaptured one sucker in 2002 when we had 133 PIT-tagged fish in the population. This equates to a population of 3,591 suckers. 
The small sample size makes it impossible to accurately estimate stocking survival or current population numbers. Based on preliminary data, early estimates place the Lake Havasu razorback sucker population at 1,600 to 3,600 fish. This would place survival rates between 5 to $12 \%$, which is quite similar to survival rates in Lake Mohave (Marsh, oral communication).

\section{Status and Existing Risks}

The flannelmouth sucker is the only native fish species which is thriving in the study area, or for that matter, has improved its status in the lower main stream river. Its numbers have expanded to several thousand; however, recruitment maybe tenuous at best and supplemented by occasionally strong year classes.

The factors that contribute to its success are poorly understood and warrant further investigation. However, the fish are prolific, fast growing, and may possess some behavior to avoid predation. It also appears there are relatively low numbers of predators in its preferred habitat which is contributing to their survival. Unfortunately, those conditions are subject to change and are not wide spread.

Laughlin Lagoon was dredged and deepened in 2000. Prior to this, it was shallow and daily fluctuations in the river stage caused cycles of flooding and drainage which exposed much of this lagoon into mudflats. Dredging deepened the entrance and created over $1 \mathrm{~km}$ of deep habitat that is ideal for centrarchids such as bluegill, green sunfish, and largemouth bass. Dredging has also increased the volume of the backwater, resulting in increased volumes of water that flow into and out of the lagoon during the daily filling and drainage cycle. The location of one of the major spawning areas just upstream of the lagoon's entrance suggests newly hatched suckers may be more vulnerable to be entrained into the lagoon which now has higher numbers of predators.

Another threat is the inevitable development of the area. There are plans to construct a marina inside the lagoon as well as another bridge that would span the river. It is doubtful that native species would benefit from construction, increased boat traffic, and pollution, especially near this known spawning area.

Based on CPUE data, razorback sucker numbers during the past four years have been declining with time. Unlike Lake Mohave, where fish persisted for nearly 5 decades, suckers can be lost not only through Parker Dam, but also through the Central Arizona Project and Metropolitan Water District's pumping plants. Razorback suckers have successfully passed through these and similar structures, but again, it is not the rate of successful passage that is worrisome, it is the rate of over-all loss (Marsh and Kesner, 2000; this report). Large numbers of suckers are no longer being stocked into Lake Havasu.

The migratory behavior of maturing adults is unknown. For many other species, young adults have more of a tendency to range from their core population (Chart and Bergersen, 1992). If this is actually the nature of maturing razorback sucker juveniles, young adults may be more prone to loss than older, more sedentary adults.

Virtually nothing is known regarding the status of bonytail. Only one bonytail was captured in the river, but several have been taken in Lake Havasu. An angler recently reported catching one while fishing with meal worms. If bonytail were inhabiting the same habitats as razorback suckers, we would have expected to have captured more than 100 based on razorback sucker returns. It is more likely they are utilizing deeper habitats found in the lower portion of the reservoir where sampling didn't occur or its possible they simply haven't survived.

Annual monitoring should be increased to a minimum of two sampling efforts, one conducted in late February or early May for razorback suckers in the upper reservoir and river and another in lower portions of the reservoir during late May and early April for bonytail. 


\section{Telemetry Studies}

The movement and behavior of razorback and flannelmouth suckers were studied using telemetry equipment. The objective was to determine where resident fish were spawning and examine post-stocking related stress.

\section{Resident Fish Tests}

Twenty resident (each) razorback sucker and flannelmouth sucker were captured and implanted with radio transmitters at either Big Bend State Park, Nevada, or Park Moabi, California. Fish were implanted with transmitters in hopes they would lead us to spawning sites. Eight boat and three helicopter surveys searched for the fish between Davis Dam and the upper portion of Lake Havasu. Unfortunately, we soon lost contact with the fish. We believe the reason contact was lost stemmed from the equipments limited range and depth. Either the fish moved outside the study area or had moved to a depth $(>4 \mathrm{~m})$ where the transmitters could not be detected.

Eighteen-month radio (40 MHZ) transmitters with self-contained antennae were selected because of the long-term duration of the study. We believed this transmitter type would provide information over two spawning seasons. Lost contact of the fish is perplexing. Even with mortality, signals should have been detected unless fish moved to depths $>4 \mathrm{~m}$, which would dampen signal transmission. The transmitters we used had internal antenna that unfortunately produce a signal that is supposedly $25 \%$ weaker than transmitters with external antennae. The internal antenna was selected since it did not have to tail out of an abdominal wound. Fish implanted with external antennae are more prone to abdominal infections and mortality. We suspect poor signal performance and possibly fish moving toward deeper habitats limited detection.

\section{The Importance of Physiology and Behavior in Survival}

The use of standard hatchery techniques in the production and stocking of endangered or economically important fishery stocks has drawn considerable attention lately (Brown and Day, 2002). Survival related issues have persisted in the reintroduction of native fish in the Colorado River for over two decades (Minckley and Deacon, 1991; Mueller and Marsh, 2002).

Past efforts to stock razorback suckers have been plagued by predation and what appears to be poor conditioning that results in chronic fatigue which may lead to mortality (Marsh and Brooks, 1989; Burdick and Bonar, 1997; Mueller and Foster, 1999). Several researchers have questioned the manner in which hatchery fish are raised and stocked but few studies have examined these issues (Marsh and Brooks, 1989; Burdick and Bonar, 1996; Mueller and Foster, 1999).

We encountered further supporting evidence. Four juvenile razorback suckers were captured downstream of Davis Dam that were originally stocked in Lake Mohave. The only way those fish could have reached their collections site was to have traveled through Davis Dam and its power plant (i.e., successful turbine passage). The likelihood of $25-30 \mathrm{~cm}$ fish successfully surviving passage through turbines has been shown to be remarkably small $(<.01)$ (Nibling and Liston, 1992). For us to encounter that many suggests substantial numbers of juvenile suckers were entrained and the vast majority killed. This may partially explain the relatively low survival rates $(<12 \%)$ being experienced in Lake Mohave (Marsh oral communication).

We tested the post-stocking dispersal of razorback suckers, feeling that downstream drift could be a symptom of chronic stress, especially when fish are being released in flowing habitats. Hatchery protocols that have worked effectively for recreational species appear to be far less effective for some native fishes. 
Razorback suckers thrive in ponds or raceways. Nutritious hatchery feeds have been developed and when practical, ponds are enriched to encourage zooplankton. Feeds are administered by hand or from trickle feeders. Hatcheries are able to produce large numbers of razorback suckers cheaply, but the poor survival of hatchery-introduced suckers raises questions regarding their ability to compete and survive. Pond reared suckers are unaccustomed to swimming in currents or foraging for natural foods.

I question whether hatchery produced razorback suckers possess the necessary survival skills and stamina to survive. It must be remembered that native fish are being stocked upon existing nonnative fish communities that are at carrying capacity. Recreational stocking on the other hand, is normally conducted to bolster depleted stocks.

\section{Site Acclimation and Physical Conditioning Tests}

Stocking dispersal (30 day) was examined during the past 5 years using eight test groups (15 fish each) of razorback sucker and telemetric equipment. Fish were released in three different habitats: (1) Lake Powell, (2) a small seasonal backwater on the Green River, and (3) Laughlin Lagoon ( $>30$ ha) on the Colorado River. Subgroups were released after being: (1) thermally acclimated to local water conditions, (2) site acclimated 3 to 7 days prior to release, and (3) physically conditioned to flow.

Post-stocking dispersal was rapid and declined with time for all tests. Most movement was detected within 2 weeks of release. Dispersal in the Green River was pronounced ( $0=69.5 \mathrm{~km} / \mathrm{month})$ and significantly (Kruskal-Wallis, $P<0.01)$ greater than either the Lake Powell $(0=3.73 \mathrm{~km} / \mathrm{month})$ or Laughlin Lagoon $(0=$ $7.72 \mathrm{~km} / \mathrm{month}$ ) groups. Fish sought and resided in slack water habitats that provided adequate cover. Siteacclimation tests were inconclusive but downstream dispersal was significantly (Wilcoxon $P<0.05$ ) less for flow-conditioned fish $(0=1.89 \mathrm{~km} /$ month $)$ compared to pond-reared fish $(0=7.73 \mathrm{k} / \mathrm{month})$.

I believe that pronounced downstream drift is a symptom of chronic stress that degrades performance and the chances for survival. Data suggest razorback sucker dispersal can be significantly reduced if fish are preconditioned to flow and stocked in moderately large ( $>30 \mathrm{ha}$ ) backwater habitats. Literature suggests physical conditioning may have other attributes, including: increased growth, better stamina, and more mucus production. Better swimming skills and increased stamina may reduce predation.

While our site acclimation tests were inconclusive, a recent study on the Green River suggests longer periods of acclimation may improve survival. Modde (FWS, oral communication) recently reported that razorback suckers held in backwaters for one year had nearly three times the return rate, compared to suckers released directly into the river.

Based on these studies, we recommend that razorback suckers be preconditioned to flow prior to release. Downstream dispersal may not be a concern in reservoir releases; however, physical conditioning also improves growth and swimming stamina that may increase their ability to escape predators. Fish should be stocked in large backwater complexes and if possible held for several weeks, if not months before being released.

A more detailed description of this test can be found in:

Mueller, G.A., Marsh, P.C., Foster, D., and Burke, T., 2003, Factors influencing post-stocking dispersal of razorback sucker: North American Journal of Fisheries Management, vol. 23, p. 270-275. 


\section{Stocking Risk Assessment}

Managers have been stocking native fish in the lower Colorado River for over two decades. The reasons have varied. The flannelmouth sucker was one of the first stocked (1976). Wild flannelmouth suckers were captured and translocated for black fly abatement. Some years later razorbacks were stocked for the same reason. Bonytail were stocked into Lake Mohave to augment an existing population and stocked downstream to reestablish the species in Lake Havasu. Stocking protocols for the razorback sucker have been similar, to augment and reestablish populations, but they have also been stocked for mitigation purposes.

The choice of stocking sites has been generally driven by logistics, politics, and convenience. The goal of stocking Lake Mohave was population specific but sites varied all over the reservoir. The ultimate goal was to augment existing communities. Fish were stocked adjacent to rearing areas and at common access points. The same was true for bonytail.

Stocking downstream of Davis Dam has generally depended on formal or informal agreements among state and federal agencies. Federal listing of the razorback sucker, bonytail, and Colorado pikeminnow has caused its own unique challenges concerning the protection afforded the species under the Endangered Species Act. Precedents have been set for razorback sucker and bonytail, since both now exist in the river. However, differences in philosophy and issues pertaining to legal status have prevented the Colorado pikeminnow from being reintroduced. How these differences will play out only time will tell.

To our knowledge, no attempt has been made to analyze stocking locations for any of the endangered fishes in the lower basin. The question of what is the most secure reach of river for these fish to my knowledge has not evaluated. More often than not, fish are stocked at the shortest route between the rearing pond or hatchery to the closest boat ramp. Documentation of sucker passage through Davis Dam indicates this approach may not be prudent.

The advent of Global Information System (GIS) programs and data bases provides a robust method of assessing habitat types. A simple stocking assessment model was developed as an example of how this technology could be used to best determine where fish should be stocked to optimize their chances for survival.

Susan Broderick and Debra Callahan (oral presentation 2000) developed a stocking risk assessment for the lower Colorado River using ArcView GIS, ArcView Spatial Analyst, and ArcView Model builder. The programs created a visual map that prioritized river reaches based on known survival risks such as: location of diversions, type of dam withdrawal (surface or hypolimnetic), presence and surface area of large backwaters, length of unobstructed river reach, and recent occurrence of razorback sucker.

They categorized or ranked specific reaches of river using a 1-6 rating system; 1 being poor and 6 being the best chance for survival. Lake Mead and upper Lake Mohave received the highest ranking, a 6 . The reach below Davis Dam including upper Lake Havasu, received a ranking from 5-6. Lower Lake Havasu downstream to Parker Dam received a poor rating of 2 . The model can be easily modified or updated. Figure 2.1 (fold-out) shows the color coded representation for the reach between Davis and Parker Dams. If you have any questions, please contact either Susan (303-445-2235) or Debra (303-445-2235). 


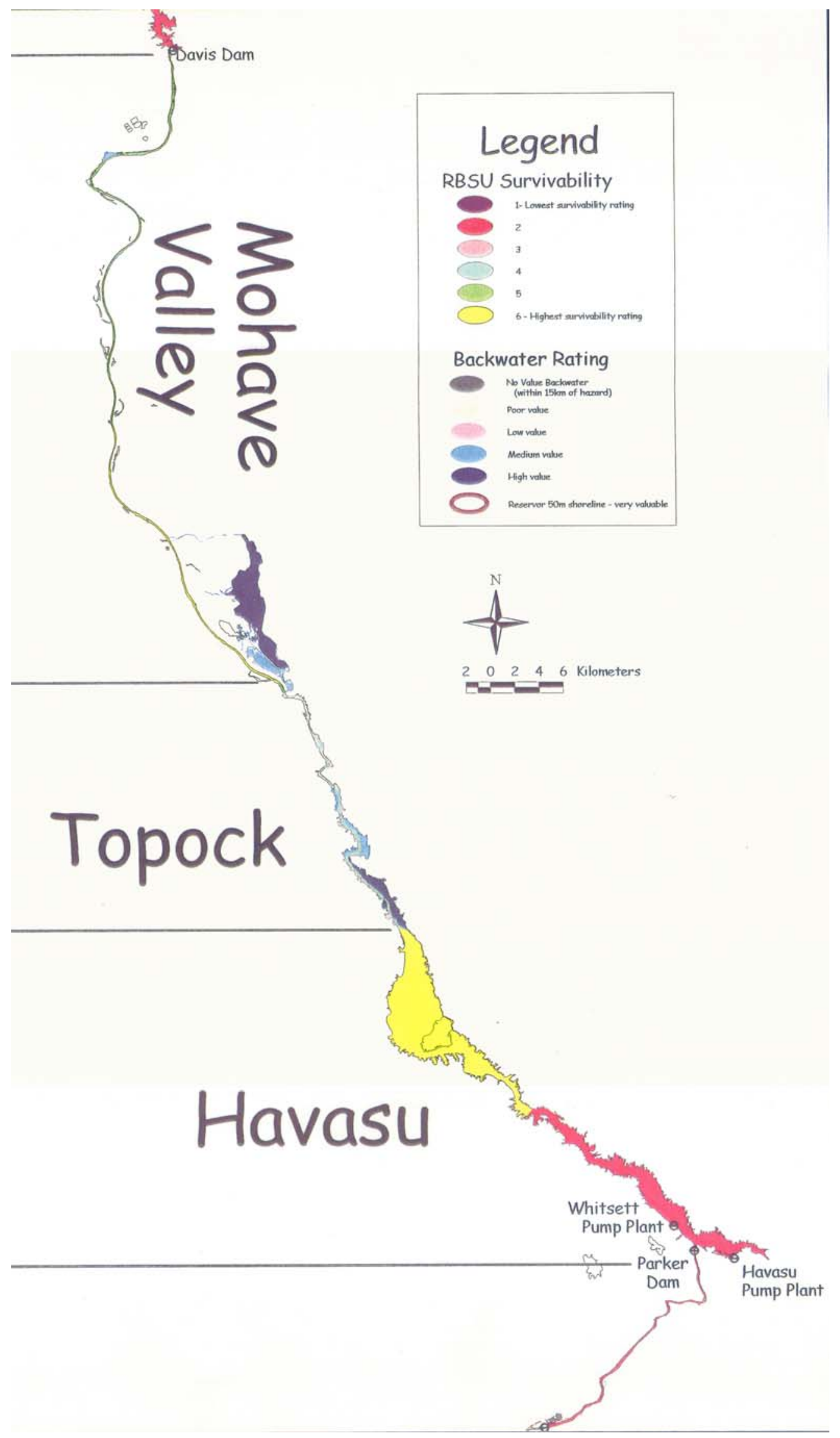




\section{Bibliography for the Big River Fishes}

A good deal of information has been written concerning the native fish of the Colorado River. This information is scattered in scientific journals, agency reports, annual and status reports, and in files. The first attempt to pull this information together occurred in 1980 when Richard Wydoski wrote the Annotated Bibliography for Aquatic Resource Management of the Upper Colorado River Ecosystem. This bibliography was published by the Fish and Wildlife Service as Resource Publication Number 135. It provided researchers the most complete source of information pertaining to the aquatic resources of the Colorado River.

During the past two decades there have been attempts to supplement or update Wydoski's bibliography. Unfortunately, these efforts received little or no circulation. To resolve this problem and make this information more available, Dr. Paul Marsh and Carol Pacey developed the 'Bibliography for the Big River Fishes, Colorado River.' This document contains nearly 2,000 references pertaining to the razorback sucker (Xyrauchen texanus), bonytail, (Gila elegans), humpback chub (Gila cypha), Colorado pikeminnow (Ptychocheilus lucius), and flannelmouth sucker (Catostomid latipinnis). The bibliography covers literature and reports produced up to January 1, 2001. The bibliography is in Excel format and the search mode is userfriendly. Nearly 200 copies of the program were distributed on CD's. An abridged version can be accessed on the Internet at:

www.fort.usgs.gov/pubs/co fishbib/co fishbib.html. CD copies are still available and requests should be made to Gordon_A Mueller@,usgs.gov. 


\section{The Role of Stocking in Management and Recovery}

The primary purpose of stocking endangered fish is to reestablish populations. Whether stocking simply maintains a presence for the species or establishes self sustaining communities is dependent on the species' ability to adapt and reproduce under existing environmental conditions. The reintroduction of native fishes back into their historical ranges seems fairly straight forward, however, we seldom recognize all the factors that caused their original demise. Three decades of stocking endangered fishes has shown that unless these bottlenecks are identified and adequately addressed, recruitment failure will continue to occur.

Millions of small razorbacks have been stocked in the mainstream and larger tributaries with little or no success. Predation is undoubtedly a major factor attributing to loses. Studies conducted in the upper basin have found a similar correlation of size with survival (Burdick 2003). Burdick recommended that only suckers $>20 \mathrm{~cm}$ be stocked and that the role of site acclimation and survival be further investigated. Marsh and Brooks (1989) recommended similar actions in the lower basin nearly 15 years earlier.

During the past decade, more than 85,000 larger $(>25 \mathrm{~cm})$ suckers have been stocked in an attempt to counter predation losses, but unfortunately, survival rates continue to remain low and may be less than $10 \%$. Survivors have either joined or created new spawning communities. These fish are starting to spawn and while larvae have been detected, natural recruitment has not. Young natives continue to fall victim to predators.

One of the primary challenges in measuring stocking survival is to recapture adequate numbers of fish. Unfortunately, this has been difficult due primarily to poor survival. Initial information suggests current augmentation efforts for the razorback sucker are falling substantially short $(>15 \%)$ of expected survival and repopulation goals. Even less information is available for the bonytail. We simply are unsure whether our sampling programs are ineffective or the fish simply have not survived.

Poor survival combined by the outcome of the telemetry experiments raises doubt regarding the performance of hatchery-reared fish and our perceived notion these communities can co-exist with sport fishes. After nearly two decades, it appears a reassessment of goals and objectives, as well as the stocking location and methods being used to rear and reintroduce fish are warranted. This chapter provides some alternative methods that may increase the likelihood of recruitment and discusses other associated issues.

\section{Bonytail, Flannelmouth, and Razorback Suckers: Contrasting Survival Stories}

The flannelmouth sucker represents the first successful reintroduction of a native fish in the main stem Colorado River. Historically they were rare in the mainstem with only five collections documented prior to 1975 (Minckley, 1973). A single stocking of 611 flannelmouths and the thousands of razorback suckers that were stocked presents an interesting and revealing paradox.

The rapid success of the flannelmouth in view of the stocking failure of razorbacks has prompted biologists to ask why flannelmouths could survive and produce young when razorback suckers have not. Both the flannelmouth and razorback are similar in size, color, and shape and evolved in the Colorado River. So why has the flannelmouth, which was historically rare, out performed the razorback which was once abundant in the main stem?

The answer may lay in the dramatic physical and biological changes that have taken place in the main stem river. It also raises some impelling questions regarding stocking philosophies, targeted species, predator/prey relationships, and the role of physical habitat.

\section{Stocking Comparisons}

The first obvious difference in the stocking approaches is the source of the fish. Wild fish taken from the Paria River were used to stock flannelmouth while bonytail and razorback suckers that were stocked were produced in hatcheries. The wild suckers undoubtedly possessed survival skills that the hatchery-reared fish did not. They were accustomed to flow, finding natural foods, and recognizing and avoiding predators. Their 
transition was relatively simple, they did not have to waste precious energy learning these skills. Hatchery reared fish on the other hand did not possess these skills. Miller (1954) showed that stream reared trout outperformed hatchery-reared trout and similar results have been reported for animals used by terrestrial programs (Conant, 1988; Griffith and others, 1989). Physical and behavioral stress associated with the transition demands time and tremendous energy reserves. Stressors are accumulative in nature and can lead to poor performance and severe cases lead to chronic fatigue and death (Wydoski and others, 1976).

\section{Habitat Preference}

The second obvious factor deals with the habitat selected by each species. The upstream portion of the study area is represented by channelized river while the lower reach contains vast expanses of off-channel wetlands. Spawning razorbacks prefer the latter while flannelmouth suckers remain upstream in the channelized portion of the river year-round (Figure 5.1).

Flannelmouth suckers represent the most common sucker in the Colorado River basin. They are most abundant in large to medium sized tributaries that are higher gradient and are characterized by cooler temperatures, rockier substrates, and are channelized. Adults avoid reservoirs or backwaters and are considered a stream fish.

Flannelmouth suckers have successfully adapted to the physical habitat changes currently found immediately downstream of Davis Dam. Historically the lower river was shallow, warm, sandy, and turbid. Operation of Davis Dam has scoured the immediate river bed, leaving the channel armored with rock and large gravels. Today, the river more closely resembles a higher gradient tributary. Flannelmouth distribution suggests they concentrate in this area and tend to avoid downstream reaches dominated by drifting sand, warmer temperatures, and numerous backwaters that are more common near Lake Havasu. Their preference for channel habitats would reduce their exposure to predators such as largemouth bass, sunfish, and bullhead (Figure 5.2).

Habitat preference for razorback suckers is different, reflecting a dependence for floodplain wetlands that were more abundant prior to human settlement. The vast expanses of Topock Swamp, once estimated at $1,740 \mathrm{ha}$, is now isolated from the river by a levee (Beland, 1953). It is easy to understand why off-channel habitats served as nurseries for their young and why they were preferred by adults (Bradford and Gurtin, 2000) (Figure 5.1). Razorback suckers were essentially a slack water species, which helps explain their ability to spawn almost anywhere. Today, remnants of those habitats are crowed with resident nonnative predators (Figure 5.2).

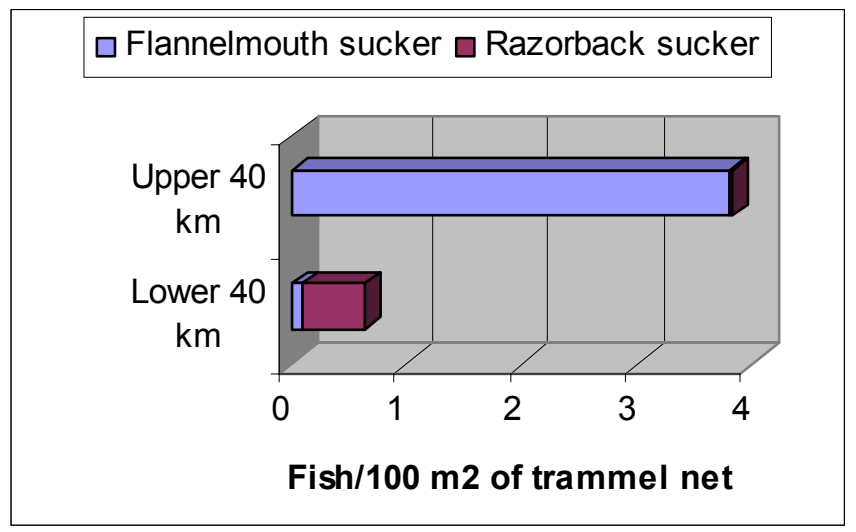

Figure 5.1. Graph showing the relative abundance of razorback and flannelmouth suckers in the upper and lower $40 \mathrm{~km}$ of river found between Davis Dam and Lake Havasu, 1999-2002. 


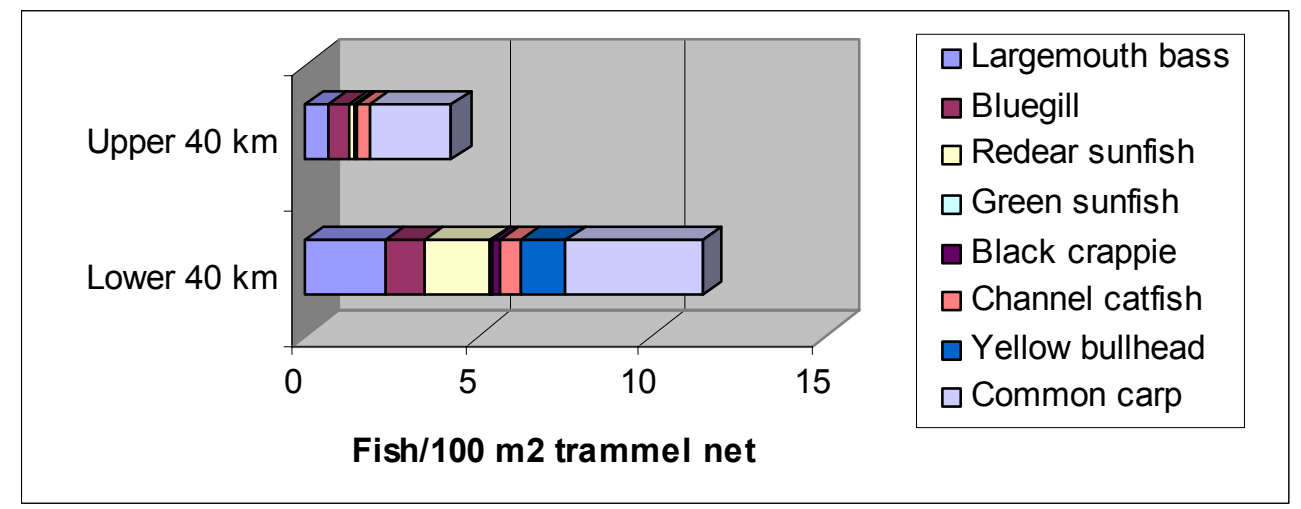

Figure 5.2. Summary graph showing the relative abundance of suspected non-native predators in the upper and lower $40 \mathrm{~km}$ of river found between Davis Dam and Lake Havasu, 1999-2002.

Flannelmouth suckers were always observed in relatively swift water $(>.5 / \mathrm{m} / \mathrm{sec}$.) and were usually found in schools that were closely associated with the bottom. Razorbacks were found under similar conditions but they were most commonly seen alone. More often they were observed in areas with little or no current. Typically, they were found in off-channel areas and often observed near the surface or somewhere in the water column. On one occasion we saw three razorback suckers together in slack waters near Needles. Their preferred habitats not only contain high concentrations of predators but their swimming mannerisms and planktonic feeding may increase their exposure to bottom feeding predators (i.e., catfish).

Another factor that may influence their survival is their migratory or roving behavior. Although very little is known regarding the movements of these fish, there is substantial evidence both can travel substantial distances (Thieme, 1997; Chart and Bergersen, 1992). Typically, older fish are more sedentary while younger suckers are more apt to move, especially in riverine systems. That does not seem to be the case for the study area. Distribution patterns are quite different.

Flannelmouth suckers are concentrated in the $30-\mathrm{km}$ reach downstream of Davis Dam. Only one flannelmouth sucker has been captured in Lake Havasu and less than $1 \%$ of our suckers were collected downstream of the Nevada-California state line. Our observations support reports that they avoid reservoirs. Their use of the upstream reach suggests they have distanced themselves from large pelagic and backwater predators as well as possible loss or displacement through water diversions or Parker Dam.

Razorback suckers on the other hand were more solitary and prone to wander and may be more apt to enter diversions or pass downstream through dams. We did recapture eight razorback suckers that had successfully passed through Davis Dam. It is quite possible young adults are more prone to displacement than older fish.

The suckers also spawn under different conditions. Large ( $>100$ fish) schools of fish were observed in the main river channel near Laughlin Lagoon and adjacent to the ruins of Fort Mohave. These fish spawned in the current $(>0.5 \mathrm{~m} / \mathrm{sec})$ and at depths $>2 \mathrm{~m}$. Observed densities of nonnative fishes appeared low with only a few channel catfish and carp observed. Larval flannelmouth suckers were taken at the Laughlin Lagoon location.

By contrast, ripe razorback suckers were found in off-channel habitats. The exception was a ripe male that was captured with a small group of spawning flannelmouth suckers. The majority of razorback suckers spawning is suspected downstream of Needles. This may change as young stocked fish mature. While razorbacks have substantial riverine habitat to spawn in, it appears they are favoring slack or backwater areas. Ripe individuals and larvae were collected from the large lagoon at Park Moabi and at the Blankenship Bend area. These locations have high densities of largemouth bass, sunfish, bullhead, and channel catfish. We were unable to document any natural recruitment for razorback suckers.

By all accounts, the flannelmouth sucker populations appear quite healthy and may still be expanding. A number of year classes were found, including young-of-the-year. Young fish were far from abundant, only 
12 fish $<15 \mathrm{~cm}$ were captured. This would suggest that either this life stage was extremely difficult to capture or that juveniles suffered high losses. Rapid growth, behavioral and habitat preferences may reduce predation and provide the flannelmouth sucker with a winning survival strategy in select portions of this highly modified river.

Much less is known about the bonytail. The last large relic population of bonytail was found in Lake Mohave while smaller numbers of the fish were taken in the river just downstream of Davis Dam (Minckley, 1973). During the 1970's and 1980's bonytail were collected off rocky points in the lower reservoir. Telemetry studies suggested fish remained in deeper portions of the reservoir during the day but moved into shore at night to presumably spawn (Marsh and Mueller, 1999). Bonytail have also been shown to do remarkably well in shallow pond habitats that are void of nonnative fishes. Current studies in the Cibola High Levee Pond have shown a naturally reproducing bonytail population numbering in the tens of thousands (Mueller and others, 2002[www.fort.usgs.gov/products/pubs/11000/11000-A.pdf]).

It appears less than a dozen bonytail have been collected from the 5,000 stocked fish. From those returns, we know some bonytail have survived; however, not enough information is available to comment on possible survival rates.

One of the primary problems is that very little effort has gone into contacting these fish or their possible young. Most organized efforts have focused on collecting razorback sucker which spawn earlier and at distinctly different locations. Additional sampling efforts should be conducted in the reservoir during the months of April and May when these fish are suspected to spawn. A summary of some suspected factors is presented in Table 5.1.

\section{Results of the Recent Endangered Fish Stocking Programs}

Agencies in the lower basin have successfully (re)established spawning populations of flannelmouth and razorback suckers in the lower basin. While razorback suckers are successfully spawning and producing larvae, we found no evidence to suggest their young have or will survive. Predation continues to be a barrier toward recruitment. Agency intervention is the only thing postponing extinction of the bonytail and razorback sucker in the basin. Recovery does not appear feasible without some brake through in recruitment.

It is quite likely that bonytail are also spawning and possibly producing larvae. Unfortunately, we simply have not had the resources or time to adequately monitor their progress. Monitoring efforts should be organized to sample during their suspected spawning season (April-May). Larval light traps should also be used since they attract bonytail larvae (Mueller and others, 2002).

Not all the news is bad. Bonytail and razorback suckers have demonstrated the unique ability to spawn in both riverine and oxbow communities. More importantly, when stocked by themselves, both species develop healthy offspring and thriving communities. The key to recruitment is the absence of nonnative predators, even isolated communities demand continued management. These communities remain highly susceptible to recolonization by exotic species through accidental or deliberate transfer by man, animals, or migratory birds.

While recovery is the ultimate goal under the Endangered Species Act, we should not loose sight of practicality. State and federal agencies in the lower basin have been aggressively stocking portions of the Colorado River and its reservoirs, but more importantly, they have started to develop off-channel refuge communities. This concept was developed by W.L. Minckley and many feel it represents the only practical approach we have today in developing self-sustaining populations of native fishes (Minckley and others, 2003).

Overwhelming predation, combined by continued water depletions, makes recovery of the species within the river highly unlikely. Their fate has been sealed by the dependence on the river of 30 million water users in the United States and Mexico. Societies' dependence on water makes native fish recovery economically and politically doubtful, and perhaps impossible. Four decades of research, coupled with failed stocking programs, have shown us that larger adults can be stocked but they cannot be expected to produce young that survive. Predation is simply too great and we simply do not have the technology or willingness to remove these economically important recreational fisheries. 
Table 5.1. Summary of possible survival factors with the conflicting survival strategies used by flannelmouth and razorback suckers.

\begin{tabular}{llll}
\hline Factors & Flannelmouth & Razorback & Bonytail \\
\hline Source of fish & Wild & Hatchery & Hatchery \\
Habitat preference & Channel & Backwaters & Reservoir? \\
Distribution & Localized & Wide & Reservoir? \\
Predator pressure & Medium & High & High \\
Spawning season & Overlaps nonnatives & First to spawn & Overlaps nonnatives \\
Spawning location & Channel & Backwaters \& River & Reservoir? \\
Larvae present & Yes->12 mm & Yes ->10 mm & Unknown \\
Nurseries & Channel fringes? & Backwaters & Reservoir? \\
Defensive behavior? & Schools & No schooling observed & Schooling suspected? \\
Recruitment & YES & No & No \\
\hline
\end{tabular}

Aldo Leopold once said the art of tinkering is not to lose any pieces of the puzzle. Unfortunately, they are being lost. Society, acting through Congress, has mandated that Government agencies preserve these unique species and ecosystems through the passage of the Endangered Species Act and other environmental legislation. Unfortunately, legislation by itself does not protect the environment, only concerned citizens and agencies do. Wild populations continue to dwindle throughout the basin and in many cases are extrapated. While there are people in some circles who care, the loss of these unique fish is viewed as the elimination of a problem.

Minckley and Deacon (1991) stated, 'Native fishes of the American West will not remain on earth without active management . . ' River communities can be maintained through hatcheries and stocking large fish, however, full recovery to self-sustaining populations in the lower basin appears impossible. A smaller and more attainable goal is to establish refuge populations which will provide additional security for the species and time needed to better understand these unique fish (Minckley and others, 2003). After four decades of research and debate, the initial steps toward the construction of these facilities is slowly starting in the lower basin, but it will take the full commitment from the public as well as the resource agencies if these fish are going to survive.

\section{Recommendations}

Management Actions:

1. Expand the Lake Havasu 'roundup' to include monitoring for the bonytail. Efforts should be conducted in April and focus on exposed, rocky points in the mid- to lower portions of the reservoir in search of spawning adults and larvae.

2. Mechanically remove predators from Park Moabi Lagoon and other known spawning areas. Razorback suckers congregate in Park Moabi Lagoon each year to spawn. A seasonal removal of predators by mechanical methods (i.e., netting and electrofishing) could reduce the abundance of predators and improve young sucker survival.

3. Only stock native fish that are at least $30 \mathrm{~cm}$ or larger. Sample analysis being done by Paul Marsh (ASU) shows a strong correlation of size with survival. Survival of fish $<30 \mathrm{~cm}$ is virtually 
undetectable.

4. Hatchery produced fish should be physically acclimated to flow and site acclimated in backwaters several weeks, if not months, prior to release. This should be done for both bonytail and razorback sucker. A recent comparison of razorback sucker released in the river with those held one year in closed backwaters suggested held fish survival was nearly $300 \%$ better than non-acclimated fish (Modde oral communication). There is also some compelling evidence in salmonid research to suggest physical conditioning improves the chances of juveniles to escape predators, thus improving survival (Maynard and others, 1995).

5. Utilized GIS based modeling to help prioritize repatriation and stocking sites. The stocking risk assessment model described in this report, or a similar approach, should be refined and used to optimize stocking survival.

6. Develop additional refuge communities. Refuge communities can provide better quality fish and research opportunities that are critically needed to advance recovery. A minimum of a dozen, small $(<5 \mathrm{ha})$ ponds should be built that can be easily renovated and managed (Minckley and others, 2003).

7. Examine the feasibility of expanding flannelmouth sucker and possibly roundtail chub in the tail races of dams further downstream. The successful colonization of a species which is typically found in smaller tributaries indicates they or similar native species could thrive in similar habitats found downstream.

Research/Monitoring Needs:

1. Expand the Lake Havasu monitoring "round-up" to include a second trip in April aimed at capturing bonytail. Efforts should coincide with bonytail spawning (April) and should be made to collect bonytail larvae.

2. Coordinate helicopter reconnaissance with boat teams to confirm suspected sightings. Helicopter reconnaissance has proven an effective method of finding spawning groups on Lake Mohave. Unfortunately, similar attempts downstream of Davis Dam have sighted suspected razorback suckers; however, follow-up sampling has not resulted in the capture of these fish. Closer coordination is needed to determine if sightings are accurate.

3. Additional research is warranted in developing and testing culturing techniques to produce fish with greater survival skills. Factors should include: physical conditioning to flow, conversion of diets to natural food items, predator recognition, predator escape issues, and the possible stocking of more vigorous habitats using translocated fish that have made the transition from hatchery to wild.

4. Refine stocking risk assessment models. Models could help increase the survival of stocked fish and help prioritize the most logical locations where fish should be reintroduced. This should better utilize cultured fish and increase the chances for program success.

5. Examine predator prey interactions. The most prevalent issue threatening recovery is nonnative predation. Literally millions of dollars are being spent in the removal of suspected nonnative predators. However, the extent of removal necessary to trigger a response by native communities is simply unknown. Refuge communities provide the only opportunity where controlled experiments can be conducted.

6. Examine the migratory behavior of sexually maturing natives. Virtually nothing is known regarding the movement of young, sexually maturing natives. It is quite possible this particular life stage is more prone to migrate, extending the range of the species than older, mature adults. If so, this may make them more susceptible to entrainment and loss to diversions and power plant passage.

7. Continue to refine survival estimates. 


\section{Acknowledgments}

This project would not have been possible without the support of local agencies. Special thanks goes to

Tom Burke and his BOR staff who generously provided equipment, facilities, and manpower, and to Alan Conklin of the Nevada Division of State Parks for allowing us to stage field surveys from his park maintenance yard, and to Chris Hayes of the California Department of Fish and Game (CDFG) for field help. We wish to acknowledge the following biologists who helped with field work: Mike Schwemm (ASU), Dean Foster (USGS), Chris Crawforth (AGFD), Jen Silverston (NPS), Al Doelker, Tom Knowles (BLM), Mike Burrell (NDOW), Tom Burke, Paul Aguirre, Ty Wolters, Billy Waddilove, Nathan Lenon, Mat Iglitz, Caireen Ulepic, John Nelson, Mike Morris, Judd Sechrist, Eric Best (BOR), Lynn Watson, Jim Stolberg, David Mueller and many others. Telemetry work was accomplished through the help of: Brian Kessner, Mike Schwemm (ASU), Paul Aguirre, Mark Santee, Greg Clune, Joe Kahl Jr., Ty Wolters, Greg Finnegan and the BOR dive team. The stocking risk model was developed by Susan Broderick and Deb Callahan (BOR). The Bibliography of the Big River Fishes, Colorado River was developed by Paul Marsh and Carol Pacey (ASU). Much of the field sampling and data entry was coordinated by Rich Wydoski. Funding and support for the project came from the USGS, BOR, and other mentioned agencies. Collecting permits were issued by FWS, AGFD, CDFG, and NDOW. The report was edited and formatted by Dora Medellin and review comments were made by Kirk Kock (BLM), Chuck Minckley (FWS), Bill Persons (AGFD) and Tom Burke.

\section{References Cited}

Anderson, B.E., 2001, The socio-economic impacts of the Lake Havasu Fisheries Improvement Program: Submitted to the Bureau of Land Management, Lake Havasu City, Arizona.

Beland, R.D., 1953, The effect of channelization on the fishery of the lower Colorado River: California Fish and Game, vol. 39, no., 1, p. 137-140.

Bradford, R.H., and Gurtin, S.D., 2000, Habitat use by hatchery-reared adult razorback sucker released into the lower Colorado River, California-Arizona: North American Journal of Fishery Management, vol. 20, p. 154-167.

Brown, C., and Day, R.L., 2002, The future of stock enhancements, lessons for hatchery practice from conservation biology: Fish and Fisheries, vol. 3, p. 79-94.

Burdick, B., 2003, Monitoring and Evaluating Various Sizes of Domestic-Reared Razorback Sucker Stocked in the Upper Colorado and Gunnison Rivers: 1995-2001. Recovery Program Project Number 50, U.S. Fish and Wildlife Service, Colorado River Fishery Project, Grand Junction.

Burdick, B.D., and Bonar, R.B., 1997, Experimental stocking of adult razorback sucker in the upper Colorado and Gunnison Rivers: Recovery Program Project Number 50, U.S. Fish and Wildlife Service, Colorado River Fishery Project, Grand Junction.

Chart, T.E., and Bergersen, E.P., 1992, Impact of mainstream impoundment on the distribution and movements of the resident flannelmouth sucker (Catostomidae: Catostomus latipinnis) population in the White River, Colorado: Southwestern Naturalist, vol. 37, p. 9-15.

Conant, S., 1988, Saving endangered species by translocation: BioScience, vol. 38, p. 254-258.

Dill, W.A., 1944, The fishery of the lower Colorado River: California Fish and Game, vol. 30, p. 109-211.

Douglas, M.E., and Marsh, P.C., 1998, Population and survival estimates of Catostomus latipinnis in Northern Grand Canyon, and distribution and abundance of hybrids with Xyrauchen texanus: Copeia, vol. 4, p. 915-925.

Fish-n-Map Co., Lake Havasu, (www.fishmap.com), date and address unknown.

Griffith, B., Scott, J.M., Carpenter, J.W., and Reed, C., 1989, Translocation as a species conservation tool, status and strategy: Science, vol. 245, p. 477-480. 
Holden, P.B., Abate, P.D., and Welker, T.L., 2001, Razorback sucker studies on Lake Mead, Nevada, 20002001 annual report: Report PR-578-5, submitted to Nevada Department of Resources, by Bio/West, Inc. Logan, Utah.

Jonez, A., and Sumner, R.C., 1954, Lake Mead and Mohave investigations: Nevada Fish and Game Commission, Reno, $186 \mathrm{p}$.

Karp, C.A., and Mueller, G., 2002, Razorback sucker movements and habitat use in the San Juan River inflow, Lake Powell, Utah, 1995-1997: Western North American Naturalist, vol. 62, p. 106-111.

McAda, C.W., and Wydoski, R.S., 1985, Growth and reproduction of the flannelmouth sucker, Catostomus latipinnis, in the upper Colorado River Basin, 1975-1976: Great Basin Naturalist, p. 281-286.

McCarthy, M.S., and Minckley, W.L., 1987, Age estimation for razorback sucker (Pisces: Catostomidae) from Lake Mohave, Arizona-Nevada: Journal of the Arizona-Nevada Academy of Sciences, vol. 21, p. $87-97$.

McKinney, T., Persons, W.R., and Rogers, R.S., 1999, Ecology of flannelmouth sucker in the Lee's Ferry tailwater, Colorado River, Arizona: Great Basin Naturalist, vol. 59, p. 259-265.

Maynard, D.J., Flagg, T.A., and Mahnken, C.V.W., 1995, A review of seminatural culture strategies for enhancing the post release survival of anadromous salmonids: American Fisheries Society Symposium, vol. 15 , p. 307-314.

Marsh, P.C., in press, Decline of wild razorback sucker in Lake Mohave, Colorado River, Arizona and Nevada: Transactions of the American Fisheries Society.

Marsh, P.C., and Brooks, J.L., 1989, Predation by ictalurid catfishes as a deterrent to reestablishment of introduced razorback sucker: The Southwestern Naturalist, vol. 34, p. 188-195.

Marsh, P.C., and Mueller, G., 1999, Spring-summer movements of bonytail in a Colorado River reservoir, Lake Mohave, Arizona, and Nevada: USGS Open-File Report 99-103, Fort Collins Science Center, Colorado.

Miller, R.R., 1961, Man and the changing fish fauna of the American Southwest. Papers of the Michigan Academy of science, Arts, and Letters 46, p. 365-404.

Miller, R.B., 1954, Comparative survival of wild and hatchery reared cutthroat trout in a stream: Transactions of the American Fisheries Society, vol. 83, p. 120-130.

Minckley, W.L., 1973, Fishes of Arizona: Arizona Game and Fish Department, Phoenix.

Minckley, W.L., 1979, Aquatic habitats and fishes of the lower Colorado River, southwestern United States: Final report for U.S. Bureau of Reclamation Contract 14-06-300-2529. Arizona State University, Tempe.

Minckley, W.L., 1983, Status of the razorback sucker, Xyrauchen texanus (Abbott), in the lower Colorado River basin: The Southwestern Naturalist, vol. 28, p. 165-187.

Minckley, W.L., 1991, Native fishes of the Grand Canyon Regions, an obituary?, proceedings of a symposium of Colorado River ecology and dam management, Santa Fe, New Mexico. Washington D.C.: National Academic Press, 228 p.

Minckley, W.L., and Deacon, J.E., 1991, Battle against extinction, native fish management in the American West: Tucson and London, The University of Arizona Press, 517 p.

Minckley, W.L., Marsh, P.C., Brooks, J.E., Johnson, J.E., and Jensen, B.L., 1991, Management toward recovery of the razorback sucker, in Minckley, W.L., and Deacon, J.E., eds., battle against extinction, native fish management in the American West: Tucson and London, The University of Arizona Press, p. 303-357.

Minckley, W.L, Marsh, P.C., Deacon, J.E., Dowling, T.E., Hedrick, P.W., Matthews, W.J., and Mueller, G., in press, A conservation plan for the Lower Colorado River native fishes: Conservation Biology.

Moyle, P.B., 1976, Inland fishes of California: Berkeley, Los Angeles, London, University of California Press.

Mueller, G., 1995, A program for maintaining the razorback sucker in Lake Mohave: American Fisheries Society Symposium, vol. 15, p. 127-135.

Mueller, G., and Foster, D.K., 1999, A case for site acclimation in the reintroduction of the endangered razorback sucker (Xyrauchen texanus): USGS Open-File Report 99-110, Denver, Colo. 
Mueller, G.A., and Marsh, P.C., 2002, Lost, a desert river and its native fish, A historical perspective of the lower Colorado River: Information and Technology Report USGS/BRD/INR 2002-010, U.S. Government Printing Office, Denver, Colo, 69 p.

Mueller, G.A., and Wydoski, R., in press, The successful reintroduction of the flannelmouth sucker in the lower Colorado River, Nevada-Arizona-California: North American Journal of Fishery Management.

Mueller, G., and others, 1993, Use of larval light traps to capture razorback sucker (Xyrauchen texanus) in Lake Mohave, Arizona- Nevada: The Southwestern Naturalist, vol. 38, p. 399-402.

Mueller, G., Marsh, P., Knowles, G.W., 1998, Distribution, migratory behavior, and habitat use of razorback sucker (Xyrauchen texanus) in Lake Mohave, Arizona-Nevada: USGS Open-File Report 98-252, Denver, Colo.

Mueller, G., Carpenter, J., and Minckley, C., 2002, Cibola High Levee Pond, draft annual report for FY-2002: USGS-BRD-FORT, Denver, Colo, $18 \mathrm{p}$.

Nibling Jr., F.L., and Liston, C.R., 1992, Mortality of grass carp subject to entrainment at Hasayampa Pumping Plant Central Arizona Project: Bureau of Reclamation, Technical Report R-92-01, Denver, Colo.

Pacey, C.A., and Marsh, P.C., 1998, Resource use by native and non-native fishes of the lower Colorado

River,

literature review, summary, and assessment of relative roles of biotic and abiotic factors in management of an imperiled indigenous ichthyofauna: Arizona State University, Contract No. 7-MT-30-R0012, submitted to the Bureau of Reclamation, Boulder City, Nev.

Ricker, W.E., 1975, Computation and interpretation of biological statistics of fish populations: Fisheries Research Board of Canada Bulletin, no. 191.

Scoppettone, and Vineyard, 1991, Life history and management of four endangered lacustrine suckers. in Minckley, W.L., and Deacon, J.E., eds., battle against extinction, native fish management in the American West: Tucson and London, The University of Arizona Press, p. 359-377.

Thieme, M.L., 1997, Movement and recruitment of flannelmouth suckers in the Paria and Colorado Rivers, Arizona: Unpublished Masters Thesis, University of Arizona, Tucson.

Weiss, S.J., Otis, E.O., Maughan, O.E., 1998, Spawning ecology of flannelmouth sucker, Catostomus latipinnis (Catostomidae), in two small tributaries of the lower Colorado River: Environmental Biology of Fishes, vol. 52, p. 419-433.

Wydoski, R.S., Wedemeyer, G.A., and Nelson, N.C., 1976, Physiological response to hooking stress in hatchery and wild rainbow trout (Salmo gairdneri): Transactions of the American Fisheries Society, vol. 105, p. 601-606. 
Appendix

Summary tables of fish numbers, average lengths, weights, and ranges 
Table A-1. Number, length, and weight range of fish captured in the Colorado River upstream of Lake Havasu from October 1999 through May 2002.

\begin{tabular}{|c|c|c|c|c|c|c|c|}
\hline \multirow{3}{*}{$\begin{array}{l}\text { Species } \\
\text { Flannelmouth suckers }\end{array}$} & \multirow{3}{*}{$\begin{array}{l}\text { Number } \\
1,355\end{array}$} & \multicolumn{3}{|c|}{ Length (mm) } & \multicolumn{3}{|c|}{ Weight $(g)$} \\
\hline & & \multirow{2}{*}{$\begin{array}{c}0 \\
515\end{array}$} & \multicolumn{2}{|c|}{ Range } & \multirow{2}{*}{$\begin{array}{r}0 \\
1,832\end{array}$} & \multicolumn{2}{|c|}{ Range } \\
\hline & & & 38 & 850 & & 16 & 4,790 \\
\hline Razorback suckers & 238 & 416 & 245 & 608 & 937 & 148 & 2,427 \\
\hline Carp & 1,573 & 515 & 38 & 850 & 1,832 & 16 & 4,790 \\
\hline Goldfish & 36 & 346 & 139 & 465 & 884 & 56 & 2,218 \\
\hline Largemouth bass & 1,502 & 316 & 40 & 610 & 594 & 1 & 4,139 \\
\hline Smallmouth bass & 30 & 353 & 272 & 464 & 716 & 255 & 1,578 \\
\hline Bluegill & 906 & 163 & 28 & 305 & 124 & 2 & 502 \\
\hline Green sunfish & 154 & 120 & 20 & 321 & 82 & 2 & 330 \\
\hline Redear sunfish & 658 & 249 & 70 & 386 & 304 & 4 & 1,225 \\
\hline Black crappie & 64 & 210 & 75 & 465 & 258 & 2 & 763 \\
\hline White crappie & 1 & 219 & & & 132 & & \\
\hline Striped bass & 150 & 389 & 123 & 1,010 & 663 & 16 & 4,420 \\
\hline Rainbow trout & 58 & 321 & 181 & 442 & 428 & 66 & 942 \\
\hline Threadfin shad & 792 & 112 & 87 & 170 & 14 & 4 & 87 \\
\hline Channel catfish & 281 & 482 & 340 & 793 & 1,482 & 314 & 4,670 \\
\hline Yellow bullhead & 282 & 296 & 187 & 369 & 402 & 60 & 744 \\
\hline Black bullhead & 9 & 284 & 255 & 332 & 370 & 266 & 496 \\
\hline Tilapia & 1 & 288 & & & 460 & & \\
\hline Bonytail & 1 & 374 & & & 377 & & \\
\hline Red shiner & \multicolumn{4}{|c|}{ present but not counted } & & & \\
\hline
\end{tabular}


Table A-2. Light trapping location, date, and fish family of successful trap sets taken during the months of February 21 through May 23, 2000.

\begin{tabular}{|c|c|c|c|c|c|c|}
\hline $\begin{array}{l}\text { Location } \\
\text { Others }\end{array}$ & Date & \# larvae & Cyprinids & Centrarchids & Catostomids & \\
\hline \multirow{8}{*}{ Laughlin Lagoon } & $4 / 12 / 00$ & 1,031 & 1,028 & & & 3 \\
\hline & $4 / 13 / 00$ & 232 & 232 & & & \\
\hline & $4 / 13 / 00$ & 1,352 & 1,251 & & & 1 \\
\hline & $4 / 25 / 00$ & 135 & 134 & 1 & & \\
\hline & $5 / 9 / 00$ & 239 & 221 & 18 & & \\
\hline & $5 / 9 / 00$ & 377 & 374 & 3 & & \\
\hline & $5 / 23 / 00$ & 49 & 38 & 11 & & \\
\hline & $5 / 23 / 00$ & 31 & 26 & 5 & & \\
\hline \multirow[t]{6}{*}{ Boy Scout Camp } & $2 / 21 / 00$ & 0 & & & & \\
\hline & $3 / 7 / 00$ & 0 & & & & \\
\hline & $3 / 8 / 00$ & 0 & & & & \\
\hline & $3 / 9 / 00$ & 0 & & & & \\
\hline & $4 / 12 / 00$ & 248 & 246 & & 2 & \\
\hline & $4 / 26 / 00$ & 6 & 4 & & 2 & \\
\hline \multirow[t]{5}{*}{ Moabi Park } & $2 / 24 / 00$ & 0 & & & & \\
\hline & $3 / 14 / 00$ & 0 & & & & \\
\hline & $3 / 16 / 00$ & & & & $1^{\mathrm{a}}$ & \\
\hline & $3 / 21 / 00$ & 0 & & & & \\
\hline & $3 / 22 / 00$ & & & & $1^{\mathrm{a}}$ & \\
\hline Topock Bay & $2 / 23 / 00$ & 0 & & & & \\
\hline \multirow[t]{3}{*}{ Pulpit Rock } & $3 / 14 / 00$ & 0 & & & & \\
\hline & $3 / 21 / 00$ & 0 & & & & \\
\hline & $3 / 22 / 00$ & & & & & \\
\hline Total & 3,602 & & $554(98.7 \%)$ & $40(1.1 \%)$ & $8(0.2 \%)$ & \\
\hline
\end{tabular}

${ }^{\mathrm{a}}$ Razorback sucker larvae.

Water temperatures: Laughlin Lagoon, 2/9/00 $=12.1 \mathrm{EC} ; 2 / 21 / 00=13.3 \mathrm{EC} ; 3 / 8 / 00=13.3 \mathrm{EC} ; 3 / 22 / 00=$ 12.6EC. Boy Scout, 3/9/00 =11.0EC. Park Moabi, 3/7/00 =11.5EC; 3/16/00 =14.5EC; 3/21/00 =13.5EC. 
Table A-3. Light trapping location, date, and fish family of sets capturing fish during January 23 through May 10, 2001.

\begin{tabular}{|c|c|c|c|c|c|}
\hline $\begin{array}{l}\text { Location } \\
\text { Others }\end{array}$ & Date & \# larvae & Cyprinids & Centrarchids & Catostomids \\
\hline \multirow{2}{*}{ Davis Dam } & $4 / 26 / 01$ & 1 & 1 & & \\
\hline & $5 / 9 / 01$ & 5 & 5 & & \\
\hline \multirow[t]{14}{*}{ Laughlin Lagoon } & $4 / 3 / 01$ & 53 & 53 & & \\
\hline & $4 / 3 / 01$ & 154 & 154 & & \\
\hline & $4 / 6 / 01$ & 91 & 90 & & 1 \\
\hline & $4 / 6 / 01$ & 183 & 183 & & \\
\hline & $4 / 6 / 01$ & 1,049 & 1,049 & & \\
\hline & $4 / 10 / 01$ & 352 & 352 & & \\
\hline & $4 / 10 / 01$ & 160 & 160 & & \\
\hline & 4/11/01 & 256 & 247 & 9 & \\
\hline & $4 / 25 / 01$ & 197 & 197 & & \\
\hline & $4 / 25 / 01$ & 24 & 10 & 14 & \\
\hline & $4 / 26 / 01$ & 169 & 72 & 97 & \\
\hline & $5 / 8 / 01$ & 106 & 104 & & 2 \\
\hline & $5 / 9 / 01$ & 56 & 56 & & \\
\hline & $5 / 10 / 01$ & 218 & 218 & & \\
\hline \multirow[t]{3}{*}{ Big Bend Park } & $4 / 11 / 01$ & 4 & 4 & & \\
\hline & 4/11/01 & 2 & 2 & & \\
\hline & $5 / 8 / 01$ & 16 & 16 & & \\
\hline \multirow[t]{5}{*}{ Boy Scout } & $4 / 4 / 01$ & 10 & 10 & & \\
\hline & $4 / 10 / 01$ & 119 & 117 & & \\
\hline & $4 / 25 / 01$ & 242 & 214 & 25 & 3 \\
\hline & $4 / 26 / 01$ & 5 & 4 & 1 & \\
\hline & $5 / 08 / 01$ & 22 & 22 & & \\
\hline \multirow[t]{4}{*}{ Park Moabi } & $3 / 21 / 01$ & 1 & & & $1^{\mathrm{a}}$ \\
\hline & $3 / 22 / 01$ & 3 & & & $3^{\mathrm{a}}$ \\
\hline & $4 / 05 / 01$ & 13 & 8 & 5 & \\
\hline & $4 / 05 / 01$ & 15 & 11 & 4 & \\
\hline \multirow[t]{2}{*}{ Blankenship Bend } & $3 / 22 / 01$ & 3 & & 1 & $2^{\mathrm{a}}$ \\
\hline & 4/05/01 & 1 & & 1 & \\
\hline Total & 3,526 & $\begin{array}{r}3,359 \\
(95.4 \%)\end{array}$ & $\begin{array}{r}149 \\
(4.2 \%)\end{array}$ & \multicolumn{2}{|c|}{$14(0.2 \%)$} \\
\hline
\end{tabular}

$\mathrm{N}=66$ trap sets (only sets capturing fish larvae are presented).

${ }^{a}$ Razorback sucker larvae. Water temperatures: Laughlin Lagoon 2/16/01 $=11.1 \mathrm{EC} ; 3 / 13 / 01=12.0 \mathrm{EC}$. 
Table A-4. Trammel net effort and relative fish abundance (fish/100 $\mathrm{m}^{2}$ net) based for 3.7 and $1.2 \mathrm{~cm}$ trammel nets fished in the Colorado River between Davis Dam and Lake Havasu $(80 \mathrm{~km})$, ArizonaNevada-California in 2000.

\begin{tabular}{|c|c|c|c|c|}
\hline \multirow[b]{2}{*}{ Trammel net size } & \multicolumn{2}{|c|}{ Upper $40 \mathrm{~km}$} & \multicolumn{2}{|c|}{ Lower $40 \mathrm{~km}$} \\
\hline & $3.7 \mathrm{~cm}$ & $1.2 \mathrm{~cm}$ & $3.7 \mathrm{~cm}$ & $1.2 \mathrm{~cm}$ \\
\hline Net area $\left(\mathrm{m}^{2}\right)$ & 8,536 & 1,096 & 2,495 & 297 \\
\hline Number of sets & 108 & 59 & 33 & 16 \\
\hline Flannelmouth sucker & 4.83 & 2.28 & 0.08 & 0.34 \\
\hline Razorback sucker & 0.04 & 0.09 & 0.91 & 0.67 \\
\hline Black crappie & 0.01 & 0 & 0.49 & 5.38 \\
\hline White crappie & 0 & 0 & 0 & 0 \\
\hline Bluegill & 0.72 & 1.82 & 0.99 & 7.07 \\
\hline Redear sunfish & 0.04 & 0.09 & 1.65 & 1.68 \\
\hline Green sunfish & 0.06 & 1.28 & 0.08 & 1.68 \\
\hline Largemouth bass & 0.67 & 2.37 & 2.85 & 8.75 \\
\hline Smallmouth bass & 0 & 0 & 0.17 & 0 \\
\hline Striped bass & 0.17 & 0.27 & 0.21 & 0.67 \\
\hline Common carp & 2.80 & 3.19 & 7.55 & 9.42 \\
\hline Goldfish & 0.05 & 0.09 & 0.17 & 0.67 \\
\hline Threadfin shad & 0 & 0.09 & 0 & 27.93 \\
\hline Channel catfish & 0.36 & 0.27 & 1.03 & 0.67 \\
\hline Yellow bullhead & 0.04 & 0 & 2.39 & 6.39 \\
\hline Rainbow trout & 0.04 & 0.46 & 0 & 0 \\
\hline
\end{tabular}


Table A-5. Trammel net effort and relative fish abundance (fish/100 $\mathrm{m}^{2}$ net) based for 3.7 and $1.2 \mathrm{~cm}$ trammel nets fished in the Colorado River between Davis Dam and Lake Havasu $(80 \mathrm{~km})$, ArizonaNevada-California in 2001.

\begin{tabular}{|c|c|c|c|c|}
\hline \multirow[b]{2}{*}{ Trammel net size } & \multicolumn{2}{|c|}{ Upper 40 km } & \multicolumn{2}{|c|}{ Lower $40 \mathrm{~km}$} \\
\hline & $3.7 \mathrm{~cm}$ & $1.2 \mathrm{~cm}$ & $3.7 \mathrm{~cm}$ & $1.2 \mathrm{~cm}$ \\
\hline Net area $\left(\mathrm{m}^{2}\right)$ & 10,535 & 483 & 13,629 & 855 \\
\hline Number of sets & 140 & 26 & 180 & 46 \\
\hline Flannelmouth sucker & 3.85 & 3.31 & 0.09 & 0 \\
\hline Razorback sucker & 0.03 & 0 & 0.47 & 0.12 \\
\hline Black crappie & 0.01 & 0 & 0.08 & 0.59 \\
\hline White crappie & 0 & 0 & 0.01 & 0 \\
\hline Bluegill & 0.56 & 4.35 & 0.82 & 5.15 \\
\hline Redear sunfish & 0.12 & 0 & 2.12 & 2.22 \\
\hline Green sunfish & 0.04 & 2.48 & 0.03 & 0.70 \\
\hline Largemouth bass & 0.65 & 7.66 & 1.58 & 4.68 \\
\hline Smallmouth bass & 0.03 & 0 & 0.08 & 0.12 \\
\hline Striped bass & 0.17 & 1.86 & 0.35 & 0.82 \\
\hline Common carp & 2.18 & 2.90 & 2.30 & 1.29 \\
\hline Goldfish & 0.04 & 0 & 0.04 & 0.23 \\
\hline Threadfin shad & 0 & 0.21 & 0.01 & 67.51 \\
\hline Channel catfish & 0.47 & 1.86 & 0.47 & 0.35 \\
\hline Yellow bullhead & 0.05 & 0 & 0.94 & 1.40 \\
\hline Rainbow trout & 0.30 & 0.21 & 0 & 0 \\
\hline Tilapia & 0.01 & 0 & 0 & 0 \\
\hline
\end{tabular}


Table A-6. Trammel net effort and relative fish abundance (fish $/ 100 \mathrm{~m}^{2}$ net) based for 3.7 and $1.2 \mathrm{~cm}$ trammel nets fished in the Colorado River between Davis Dam and Lake Havasu $(80 \mathrm{~km})$, ArizonaNevada-California in 2002.

\begin{tabular}{|c|c|c|c|c|}
\hline \multirow[b]{2}{*}{ Trammel net size } & \multicolumn{2}{|c|}{ Upper $40 \mathrm{~km}$} & \multicolumn{2}{|c|}{ Lower $40 \mathrm{~km}$} \\
\hline & $3.7 \mathrm{~cm}$ & $1.2 \mathrm{~cm}$ & $3.7 \mathrm{~cm}$ & $1.2 \mathrm{~cm}$ \\
\hline Net area $\left(\mathrm{m}^{2}\right)$ & 10,682 & 683 & 7,129 & 446 \\
\hline Number of sets & 155 & 37 & 90 & 16 \\
\hline Flannelmouth sucker & 2.74 & 1.31 & 0.08 & 0.34 \\
\hline Razorback sucker & 0.35 & 0 & 0.30 & 0.34 \\
\hline Black crappie & 0 & 0 & 0.01 & 4.71 \\
\hline White crappie & 0 & 0 & 0 & 0 \\
\hline Bluegill & 0.58 & 4.07 & 1.61 & 15.14 \\
\hline Redear sunfish & 0.22 & 0.15 & 1.94 & 6.05 \\
\hline Green sunfish & 0.08 & 2.04 & 0.06 & 0.67 \\
\hline Largemouth bass & 0.66 & 5.53 & 2.40 & 5.05 \\
\hline Smallmouth bass & 0.02 & 0 & 0.06 & 0 \\
\hline Striped bass & 0.18 & 0 & 0.23 & 0 \\
\hline Common carp & 2.02 & 1.89 & 1.94 & 0.67 \\
\hline Goldfish & 0.05 & 0 & 0.07 & 0 \\
\hline Threadfin shad & 0 & 0.44 & 0 & 2.35 \\
\hline Channel catfish & 0.24 & 0.15 & 0.37 & 0 \\
\hline Yellow bullhead & 0.05 & 0 & 0.57 & 2.69 \\
\hline Rainbow trout & 0.10 & 0 & 0 & 0 \\
\hline Bonytail & 0.02 & 0 & 0 & 0 \\
\hline
\end{tabular}


Table A-7. Light trapping location, date, and fish family of successful trap sets taken during February 21 through May 23, 2000.

\begin{tabular}{|c|c|c|c|c|c|}
\hline $\begin{array}{l}\text { Location } \\
\text { Others }\end{array}$ & Date & \# larvae & Cyprinids & Centrarchids & Catostomids \\
\hline \multirow[t]{2}{*}{ Laughlin Lagoon } & $4 / 12 / 00$ & 1,031 & 1,028 & & 3 \\
\hline & $4 / 13 / 00$ & 232 & 232 & & \\
\hline \multirow[t]{6}{*}{$4 / 13 / 00$} & 1,352 & 1,251 & & & 1 \\
\hline & $4 / 25 / 00$ & 135 & 134 & 1 & \\
\hline & $5 / 9 / 00$ & 239 & 221 & 18 & \\
\hline & $5 / 9 / 00$ & 377 & 374 & 3 & \\
\hline & $5 / 23 / 00$ & 49 & 38 & 11 & \\
\hline & $5 / 23 / 00$ & 31 & 26 & 5 & \\
\hline \multirow[t]{4}{*}{ Boy Scout Camp } & $2 / 21 / 00$ & 0 & & & \\
\hline & $3 / 7 / 00$ & 0 & & & \\
\hline & $3 / 8 / 00$ & 0 & & & \\
\hline & $3 / 9 / 00$ & 0 & & & \\
\hline $4 / 12 / 00$ & 248 & 246 & & 2 & \\
\hline $4 / 26 / 00$ & 6 & 4 & 2 & & \\
\hline \multirow[t]{5}{*}{ Moabi Park } & $2 / 24 / 00$ & 0 & & & \\
\hline & $3 / 14 / 00$ & 0 & & & \\
\hline & $3 / 16 / 00$ & & & & $1^{\mathrm{a}}$ \\
\hline & $3 / 21 / 00$ & 0 & & & \\
\hline & $3 / 22 / 00$ & & & & $1^{\mathrm{a}}$ \\
\hline Topock Bay & $2 / 23 / 00$ & 0 & & & \\
\hline \multirow[t]{3}{*}{ Pulpit Rock } & $3 / 14 / 00$ & 0 & & & \\
\hline & $3 / 21 / 00$ & 0 & & & \\
\hline & $3 / 22 / 00$ & & & & \\
\hline \multirow[t]{2}{*}{ Total } & & 3,602 & 3,554 & 40 & 8 \\
\hline & & & $(98.7 \%)$ & $(1.1 \%)$ & $(0.2 \%)$ \\
\hline
\end{tabular}

${ }^{\mathrm{a}}$ Razorback sucker larvae.

Water temperatures: Laughlin Lagoon, 2/9/00 $=12.1 \mathrm{EC} ; 2 / 21 / 00=13.3 \mathrm{EC} ; 3 / 8 / 00=13.3 \mathrm{EC}, ; 3 / 22 / 00=$ 12.6EC. Boy Scout, 3/9/00 = 11.0EC. Park Moabi, 3/7/00 = 11.5EC; 3/16/00 =14.5EC; 3/21/00 = 13.5EC, 
Table A-7. Light trapping location, date, and fish family of sets capturing fish during the months of January 23 through May 10, 2001.

\begin{tabular}{|c|c|c|c|c|c|c|}
\hline $\begin{array}{l}\text { Location } \\
\text { Others }\end{array}$ & Date & \# larvae & Cyprinids & Centrarchids & Catostomids & \\
\hline \multirow[t]{2}{*}{ Davis Dam } & $4 / 26 / 01$ & 1 & 1 & & & \\
\hline & $5 / 9 / 01$ & 5 & 5 & & & \\
\hline \multirow[t]{14}{*}{ Laughlin Lagoon } & $4 / 3 / 01$ & 53 & 53 & & & \\
\hline & $4 / 3 / 01$ & 154 & 154 & & & \\
\hline & $4 / 6 / 01$ & 91 & 90 & & 1 & \\
\hline & $4 / 6 / 01$ & 183 & 183 & & & \\
\hline & $4 / 6 / 01$ & 1,049 & 1,049 & & & \\
\hline & $4 / 10 / 01$ & 352 & 352 & & & \\
\hline & $4 / 10 / 01$ & 160 & 160 & & & \\
\hline & $4 / 11 / 01$ & 256 & 247 & 9 & & \\
\hline & $4 / 25 / 01$ & 197 & 197 & & & \\
\hline & $4 / 25 / 01$ & 24 & 10 & 14 & & \\
\hline & $4 / 26 / 01$ & 169 & 72 & 97 & & \\
\hline & $5 / 8 / 01$ & 106 & 104 & & & 2 \\
\hline & $5 / 9 / 01$ & 56 & 56 & & & \\
\hline & $5 / 10 / 01$ & 218 & 218 & & & \\
\hline \multirow[t]{3}{*}{ Big Bend Park } & $4 / 11 / 01$ & 4 & 4 & & & \\
\hline & $4 / 11 / 01$ & 2 & 2 & & & \\
\hline & $5 / 8 / 01$ & 16 & 16 & & & \\
\hline \multirow[t]{5}{*}{ Boy Scout } & $4 / 4 / 01$ & 10 & 10 & & & \\
\hline & $4 / 10 / 01$ & 119 & 117 & & & 2 \\
\hline & $4 / 25 / 01$ & 242 & 214 & 25 & 3 & \\
\hline & $4 / 26 / 01$ & 5 & 4 & 1 & & \\
\hline & $5 / 08 / 01$ & 22 & 22 & & & \\
\hline \multirow[t]{4}{*}{ Park Moabi } & $3 / 21 / 01$ & 1 & & & & $1^{\mathrm{a}}$ \\
\hline & $3 / 22 / 01$ & 3 & & & & $3^{\mathrm{a}}$ \\
\hline & $4 / 05 / 01$ & 13 & 8 & 5 & & \\
\hline & $4 / 05 / 01$ & 15 & 11 & 4 & & \\
\hline \multirow[t]{2}{*}{ Blankenship Bend } & $3 / 22 / 01$ & 3 & & 1 & \multirow[t]{2}{*}{$2^{\mathrm{a}}$} & \\
\hline & $4 / 05 / 01$ & 1 & & 1 & & \\
\hline \multirow[t]{2}{*}{ Total } & 3,526 & 3,359 & 149 & 14 & 4 & \\
\hline & & $(95.4 \%)$ & $(4.2 \%)$ & $(0.2 \%)$ & $(0.1 \%)$ & \\
\hline
\end{tabular}

$\mathrm{N}=66$ trap sets (only sets capturing fish larvae are presented).

${ }^{\text {a }}$ Razorback sucker larvae.

Water temperatures: Laughlin Lagoon, 2/16/01 =11.1EC; 3/13/01 =12.0EC; 4/3/01 =14.0EC; 4/11/01 = $13.5 \mathrm{EC} ; 5 / 9 / 01=17.6 \mathrm{EC}$. 